\title{
Influence of landscape heterogeneity on spatial patterns of wood productivity, wood specific density and above ground biomass in Amazonia
}

\author{
L. O. Anderson ${ }^{1}$, Y. Malhi ${ }^{1}$, R. J. Ladle ${ }^{1}$, L. E. O. C. Aragão ${ }^{1}$, Y. Shimabukuro ${ }^{2}$, O. L. Phillips ${ }^{3}$, T. Baker ${ }^{3}$, \\ A. C. L. Costa ${ }^{4}$, J. S. Espejo ${ }^{5}$, N. Higuchi ${ }^{6}$, W. F. Laurance ${ }^{7}$, G. López-González ${ }^{3}$, A. Monteagudo ${ }^{8}$, P. Núñez-Vargas ${ }^{9}$, \\ J. Peacock ${ }^{3}$, C. A. Quesada ${ }^{3,6}$, and S. Almeida ${ }^{10}$ \\ ${ }^{1}$ School of Geography and the Environment, University of Oxford, Oxford, UK \\ ${ }^{2}$ Remote Sensing Division, National Institute for Space Research, São José dos Campos, Brazil \\ ${ }^{3}$ Earth and Biosphere Institute, School of Geography, University of Leeds, LS2 9JT, England, UK \\ ${ }^{4}$ Universidade Federal de Pará, Belém, Brazil \\ ${ }^{5}$ Universidad Nacional San Antonia Abad del Cusco, Cusco, Perú \\ ${ }^{6}$ Institito National de Pesquisas da Amazônia, Manaus, Brazil \\ ${ }^{7}$ Smithsonian Tropical Research Institute, Balboa, Panama \\ ${ }^{8}$ Herbario Vargas, Universidad Nacional San Antonio Abad del Cusco, Cusco, Perú \\ ${ }^{9}$ Herbario Vargas, Universidad Nacional San Antonio Abad del Cusco, Cusco, Perú \\ ${ }^{10}$ Museu Paraense Emilio Goeldi, Belém, Brazil
}

Received: 17 December 2008 - Published in Biogeosciences Discuss.: 18 February 2009

Revised: 23 June 2009 - Accepted: 21 August 2009 - Published: 8 September 2009

\begin{abstract}
Long-term studies using the RAINFOR network of forest plots have generated significant insights into the spatial and temporal dynamics of forest carbon cycling in Amazonia. In this work, we map and explore the landscape context of several major RAINFOR plot clusters using Landsat ETM+ satellite data. In particular, we explore how representative the plots are of their landscape context, and test whether bias in plot location within landscapes may be influencing the regional mean values obtained for important forest biophysical parameters. Specifically, we evaluate whether the regional variations in wood productivity, wood specific density and above ground biomass derived from the RAINFOR network could be driven by systematic and unintentional biases in plot location. Remote sensing data covering 45 field plots were aggregated to generate landscape maps to identify the specific physiognomy of the plots. In the Landsat ETM+ data, it was possible to spectrally differentiate three types of terra firme forest, three types of forests over Paleovarzea geomorphologycal formation, two types of bamboo-dominated forest, palm forest, Heliconia monodominant vegetation, swamp forest, disturbed forests and land
\end{abstract}

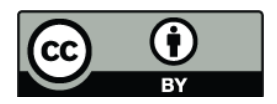

Correspondence to: L. O. Anderson (liana.anderson@ouce.ox.ac.uk) use areas. Overall, the plots were generally representative of the forest physiognomies in the landscape in which they are located. Furthermore, the analysis supports the observed regional trends in those important forest parameters. This study demonstrates the utility of landscape scale analysis of forest physiognomies for validating and supporting the finds of plot based studies. Moreover, the more precise geolocation of many key RAINFOR plot clusters achieved during this research provides important contextual information for studies employing the RAINFOR database.

\section{Introduction}

Amazonia is an important part of the global biosphere, playing a major role in influencing climate systems (Andreae et al., 2004; Malhi et al., 2008), and providing vital ecosystem services such as carbon storage and cycling (Houghton et al., 2001; Malhi et al., 2004; Aragão et al., 2009; Baker et al., 2009; Chave et al., 2009; Saatchi et al., 2009) and water cycling (Betts et al., 2004; Marengo, 2005). It is also a repository for vast stores of biodiversity (Condit et al., 2002; ter Steege et al., 2006). One of the main sources of information about the carbon dynamics and forest ecology of Amazonia has been widely dispersed networks of permanent forest plots

Published by Copernicus Publications on behalf of the European Geosciences Union. 
such as the RAINFOR network (Malhi et al., 2002; Peacock et al., 2007). Studies of these plots have generated significant insights into the spatial and temporal dynamics of the processes of forest carbon cycling, including biomass (Baker et al., 2004a; Chave et al., 2005; Malhi et al., 2006; Saatchi et al., 2009), wood productivity (Malhi et al., 2004; Baker et al., 2009; Mercado et al., 2009), wood specific density (Baker et al., 2004b), changes in growth (Phillips et al., 2002; Baker et al., 2003; Lewis et al., 2004), turnover (Phillips et al., 1994, 2004), and diversity (Phillips et al., 1994; ter Steege et al., 2000; Honorio et al., 2009).

The picture gradually emerging from these studies suggests that slow growing forests in central and eastern Amazonia, where soils are poorer, have significantly higher above ground biomass (AGB), higher wood density and larger seeds than stands in northwest and southwest Amazonia that are situated on more fertile soils (Malhi et al., 2006; ter Steege et al., 2006; Quesada et al., 2009a). However, the opposite pattern is observed in relation to forest productivity and dynamism, which is higher in western Amazonia than in central and eastern forests, possibly driven by higher soil fertility (Phillips et al., 2004; Malhi et al., 2004; Aragão et al., 2009). Furthermore, it has been shown that maximum tree $\alpha$ diversity is related to the length of the dry season (ter Steege et al., 2006). In general, taking into consideration the spatial and temporal pattern of sampling, there is good support for the hypothesis that the total biomass of the plots studied has increased over the last two decades (Phillips et al., 1998; Baker et al., 2004a).

These results have significantly influenced the way that scientists think about the interaction between tropical forests and the physical environment. However, many of these findings rest on the assumption that the permanent forest plots are a representative sample of the part of Amazonia in which they are based. In other words, uncertainties still exist as to whether the plots represent a partial sampling of landscapes that are heterogeneous at several scales. Any such systematic sampling error could challenge some of the findings of previous studies.

The implicit assumption is that a 1 hectare field plot provides a reasonable representation of regional forest structure, species composition and dynamics (Chave et al., 2004). However, to effectively and accurately scale-up these findings it is fundamentally important to consider the landscape mosaic structure, defined by Zonneveld (1989) as the "landscape unit". This sampling unit relies on spatially locating and mapping homogeneous areas in the landscape based on the pertinent available data that drives the vegetation characteristics for a region, and has been used successfully for mapping different vegetation formations in mountain regions (Franklin and Woodcock, 1997), for scaling Photosynthetic Active Radiation (PAR) in heterogeneous ecosystems (Asner and Wessman, 1997), and for identifying the spatial variability of canopy structural characteristics in Amazonia (Aragão et al., 2005).
In relation to the Amazonian RAINFOR sites, the location of study plots may be 'landscape biased' because they are part of an initiative that assembles existing plots that were set up for botanical and forestry studies. It takes the advantages to have a standardized protocol of methods for colleting field data and therefore, making possible an inter-comparison among sites. In this sense, a range of factors could introduce a bias in the sampling strategy, including: 1) access limitations (e.g. proximity to roads, research stations, towns, rivers, etc.); 2) biophysical characteristics of the forest (e.g. slope, understorey, soil moisture, flooding, etc.) and potentially: 3 ) the underlying scientific reason for setting up a plot, such as different rationale for choosing an area depending on the objective of the specific study, funding availability, etc.

In this study, we evaluate the existence and potential extent of sampling bias in the positioning of forest study plots in the RAINFOR network through the use of remote sensing data to evaluate the heterogeneity of the landscape within which the plot is embedded. Specifically we test whether the regional variations in wood productivity, wood specific density and above ground biomass revealed by the RAINFOR network could be driven by biases in plot location within landscapes. In the process of testing these hypotheses, we aim to achieve the additional goals of describing the landscape characteristics and precisely locating these important plots. As many of these plots have delivered major insights into the dynamics of Amazonian forests, and are likely to continue being monitored over the 21 st century, this work also provides a useful background dataset for the future interpretation of RAINFOR plot data.

\section{Study sites}

We evaluate the landscape and field characteristics of seven sites (45 field plots in total) covering western, central and eastern Amazonia, which have been used in intensive studies (e.g. Laurance et al., 1998; Malhi et al., 2004; Phillips et al., 2004; Lewis et al., 2004; Baker et al., 2004a, b). The geographic division of the Amazon in three main regions reflects the concentration of sites: Andean countries are considered western Amazon, Amazonas State, in the Brazilian Amazon is considered central region, and Pará state (Brazilian Amazon) is the eastern limits of the evergreen closed forest. Western Amazonian sites include: Allpahuayo, Cuzco Amazonico, Jenaro Herrera, Sucusari and Tambopata (all in Peru). Central Amazonia site is represented by Manaus region, and Eastern Amazonia site is represented by the Caxiuanã plots (Table 1). Sites were chosen on the basis of the number and the availability of the field plot data, whether research is still being carried out in these areas and on the availability of cloud-free remote sensing data (Fig. 1).

The characterization of each field plots, including plot code, central coordinate of the plot, elevation, plot shape, forest type, and Landsat ETM+ path/row and image acquisition 
Table 1. General characteristics of the sites studied. Data compiled from Malhi et al. (2004). The soil type classes are from the World Reference Base soil classification; for detailed information, see Quesada et al. (2009a).

\begin{tabular}{|c|c|c|c|c|}
\hline Site & Location & $\begin{array}{l}\text { Mean precipitation } \\
(\mathrm{mm})\end{array}$ & $\begin{array}{c}\text { Mean } \\
\text { temperature }\left({ }^{\circ} \mathrm{C}\right)\end{array}$ & Soil type \\
\hline Allpahuayo & $\begin{array}{l}\text { Northern Peruvian Amazon } \\
73^{\circ} 25^{\prime} \mathrm{W}, 3^{\circ} 56^{\prime} \mathrm{S}\end{array}$ & 2760 & 26.3 & Arenosols, Alisol, Gleysol and Plinthosol. \\
\hline Cuzco Amazonico & $\begin{array}{l}\text { Southern Peruvian Amazon } \\
68^{\circ} 57^{\prime} \mathrm{W}, 12^{\circ} 30^{\prime} \mathrm{S}\end{array}$ & 2420 & 25.5 & Cambisols \\
\hline Jenaro Herrera & $\begin{array}{l}\text { Northern Peruvian Amazon } \\
73^{\circ} 41^{\prime} \mathrm{W}, 4^{\circ} 55^{\prime} \mathrm{S}\end{array}$ & 2700 & 26.6 & Cambisols, Arenosols \\
\hline Tambopata & $\begin{array}{l}\text { Southern Peruvian Amazon } \\
69^{\circ} 17^{\prime} \mathrm{W}, 12^{\circ} 50^{\prime} \mathrm{S}\end{array}$ & 2420 & 25.2 & Alisol, Cambisols, Gleysols \\
\hline Manaus & $\begin{array}{l}\text { Centre of the Brazilian Amazon } \\
60^{\circ} 01^{\prime} \mathrm{W}, 2^{\circ} 28^{\prime} \mathrm{S}\end{array}$ & 2170 & 26.8 & Ferralsols, Podzols \\
\hline Caxiuanã & $\begin{array}{l}\text { Eastern Brazilian Amazon } \\
51^{\circ} 27^{\prime} \mathrm{W}, 1^{\circ} 43^{\prime} \mathrm{S}\end{array}$ & 2300 & 26.8 & Acrisols, Ferralsols \\
\hline
\end{tabular}

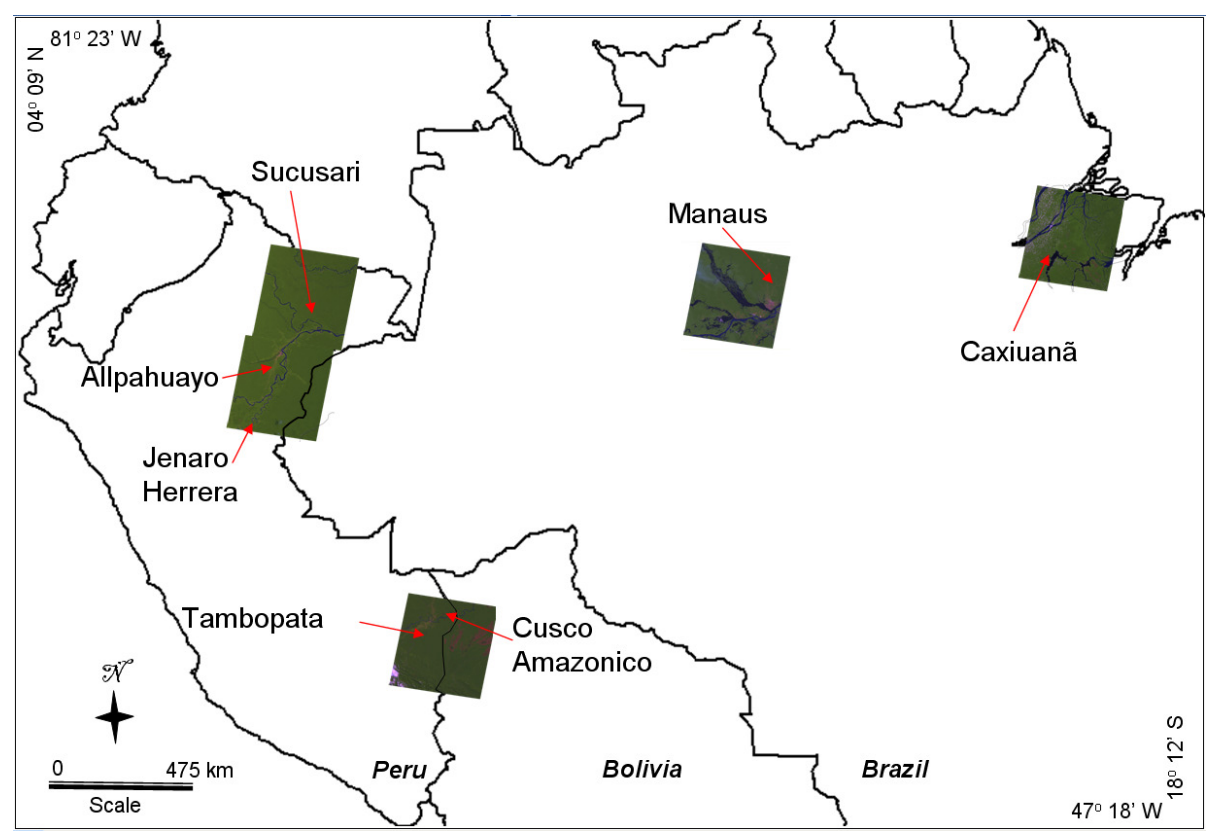

Fig. 1. Location of the 7 study sites: Western Amazonia is covered by Peruvian sites, Central Amazonia is represented by Manaus region and Eastern Amazonia encompasses Caxiuanã plots. The country limits are in black lines and the sites are indicated in an ETM+ colour composite image.

dates are depicted in Table 2. Additionally, the description of the forest types is presented in Table 3. All of the field plots are approximately 1 hectare in size, however the shape varies from square plots $(100 \mathrm{~m} \times 100 \mathrm{~m})$ to rectangular transects of: $40 \mathrm{~m} \times 250 \mathrm{~m}, 20 \mathrm{~m} \times 500 \mathrm{~m}$ or $10 \mathrm{~m} \times 1000 \mathrm{~m}$ (see Table 2).

\section{Material and methods}

\subsection{Remote sensing optical data and image processing}

Five Landsat 7/ETM+ scenes were used in this study (Table 2). These images were acquired during the dry season (August and September) when cloud free conditions predominate (Table 1). The images were imported into a dataset 
Table 2. Field plots characteristics. TF = Terra Firme, TF $2=$ Terra Firme (type 2), TF $3=$ Terra Firme (type 3 ), FAT $1=$ Forests over alluvial terrain (type 1), FAT 2 = forests over alluvial terrain (type 2), FAT 3 = forests over alluvial terrain (type 3 ), DF = disturbed forest, SW = swamp. The forest type is derived from the landscape maps in this study; detailed description is presented in Table 3.

\begin{tabular}{|c|c|c|c|c|c|c|c|c|c|}
\hline Site & $\begin{array}{l}\text { Plot } \\
\text { code }\end{array}$ & Country & $\begin{array}{l}\text { Central } \\
\text { latitude }\end{array}$ & $\begin{array}{l}\text { Central } \\
\text { longitude }\end{array}$ & $\begin{array}{c}\text { SRTM altitude } \\
\text { (mean value, in meters) }\end{array}$ & $\begin{array}{l}\text { Plot shape } \\
(\mathrm{m} \times \mathrm{m})\end{array}$ & $\begin{array}{l}\text { Forest } \\
\text { type }\end{array}$ & $\begin{array}{l}\text { Landsat } \\
\text { path/row }\end{array}$ & Image date \\
\hline \multirow[t]{3}{*}{ Allpahuayo } & ALP-03 & Peru & $-3^{\circ} 57^{\prime} 15.57^{\prime \prime}$ & $-73^{\circ} 25^{\prime} 32.93^{\prime \prime}$ & 145 & $40 \times 250$ & $\mathrm{TF}$ & $006 / 063$ & 23 Sep 2003 \\
\hline & ALP A & & $-3^{\circ} 56^{\prime} 57.94^{\prime \prime}$ & $-73^{\circ} 26^{\prime} 2.81^{\prime \prime}$ & 128 & $40 \times 500$ & $\mathrm{TF} 3$ & & \\
\hline & ALP B & & $-3^{\circ} 57^{\prime} 10.62^{\prime \prime}$ & $-73^{\circ} 26^{\prime} 14.64^{\prime \prime}$ & 136 & $40 \times 500$ & TF, TF3 & & \\
\hline \multirow[t]{4}{*}{ Caxiuanã } & CAX-01 & Brazil & $-1^{\circ} 44^{\prime} 14.65^{\prime \prime}$ & $-51^{\circ} 27^{\prime} 46.46^{\prime \prime}$ & 45 & & & $225 / 061$ & 20 Aug 2002 \\
\hline & CAX-02 & & $-1^{\circ} 44^{\prime} 36.51^{\prime \prime}$ & $-51^{\circ} 27^{\prime} 41.34^{\prime \prime}$ & 42 & $100 \times 100$ & $\mathrm{TF}$ & & \\
\hline & CAX-06 & & $-1^{\circ} 44^{\prime} 12.55^{\prime \prime}$ & $-51^{\circ} 27^{\prime} 42.52^{\prime \prime}$ & 47 & & & & \\
\hline & TEC-02 & & $-1^{\circ} 42^{\prime} 24.07^{\prime \prime}$ & $-51^{\circ} 27^{\prime} 33.12^{\prime \prime}$ & 42 & & & & \\
\hline \multirow[t]{4}{*}{ Cuzco Amazônico } & CUZ-01 & Peru & $-12^{\circ} 29^{\prime} 56.34^{\prime \prime}$ & $-68^{\circ} 58^{\prime} 25.63^{\prime \prime}$ & 200 & & FAT 2 & 002/069 & 23 Aug 2001 \\
\hline & CUZ-02 & & $-12^{\circ} 29^{\prime} 56.81^{\prime \prime}$ & $-68^{\circ} 58^{\prime} 14.54^{\prime \prime}$ & 199 & $20 \times 500$ & FAT 2 & & \\
\hline & CUZ-03 & & $-12^{\circ} 29^{\prime} 58.81^{\prime \prime}$ & $-68^{\circ} 57^{\prime} 46.65^{\prime \prime}$ & 198 & & FAT 1 & & \\
\hline & CUZ-04 & & $-12^{\circ} 29^{\prime} 57.18^{\prime \prime}$ & $-68^{\circ} 57^{\prime} 35.21^{\prime \prime}$ & 196 & & FAT 1 & & \\
\hline \multirow[t]{6}{*}{ Jenaro Herrera } & JEN-03 & Peru & $-4^{\circ} 54^{\prime} 51.14^{\prime \prime}$ & $-73^{\circ} 44^{\prime} 32.98^{\prime \prime}$ & 114 & $100 \times 100$ & FAT 1 & 006/063 & 23 Sep 2002 \\
\hline & JEN-06 & & $-4^{\circ} 54^{\prime} 45.84^{\prime \prime}$ & $-73^{\circ} 44^{\prime} 46.94^{\prime \prime}$ & 112 & & FAT 1 & & \\
\hline & JEN-09 & & $-4^{\circ} 57^{\prime} 29.21^{\prime \prime}$ & $-73^{\circ} 43^{\prime} 18.32^{\prime \prime}$ & 102 & & FAT 1 & & \\
\hline & JEN-10 & & $-4^{\circ} 53^{\prime} 56.37^{\prime \prime}$ & $-73^{\circ} 38^{\prime} 50.42^{\prime \prime}$ & 135 & & DF & & \\
\hline & JEN-11 & & $-4^{\circ} 52^{\prime} 41.56^{\prime \prime}$ & $-73^{\circ} 37^{\prime} 46.25^{\prime \prime}$ & 131 & & $\mathrm{TF}$ & & \\
\hline & JEN-12 & & $-4^{\circ} 53^{\prime} 57.36^{\prime \prime}$ & $-73^{\circ} 37^{\prime} 40.97^{\prime \prime}$ & 128 & $50 \times 200$ & $\mathrm{TF}$ & & \\
\hline \multirow[t]{16}{*}{ Manaus } & BDF-01 & Brazil & $-2^{\circ} 20^{\prime} 33.93^{\prime \prime}$ & $-60^{\circ} 05^{\prime} 47.24^{\prime \prime}$ & 116 & & $\mathrm{TF}$ & $230 / 062$ & 8 Sep 2002 \\
\hline & BDF-03 & & $-2^{\circ} 25^{\prime} 26.96^{\prime \prime}$ & $-59^{\circ} 51^{\prime} 18.08^{\prime \prime}$ & 105 & $100 \times 100$ & & & \\
\hline & BDF-04 & & $-2^{\circ} 25^{\prime} 38.90^{\prime \prime}$ & $-59^{\circ} 51^{\prime} 10.75^{\prime \prime}$ & 120 & & & & \\
\hline & BDF-05 & & $-2^{\circ} 25^{\prime} 32.80^{\prime \prime}$ & $-59^{\circ} 51^{\prime} 2.82^{\prime \prime}$ & 120 & & & & \\
\hline & BDF-06 & & $-2^{\circ} 24^{\prime} 53.94^{\prime \prime}$ & $-59^{\circ} 51^{\prime} 24.09^{\prime \prime}$ & 111 & & & & \\
\hline & BDF-09 & & $-2^{\circ} 23^{\prime} 48.92^{\prime \prime}$ & $-59^{\circ} 50^{\prime} 47.03^{\prime \prime}$ & 114 & & & & \\
\hline & BDF-10 & & $-2^{\circ} 23^{\prime} 19.92^{\prime \prime}$ & $-59^{\circ} 51^{\prime} 18.50^{\prime \prime}$ & 123 & & & & \\
\hline & BDF-11 & & $-2^{\circ} 23^{\prime} 4.72^{\prime \prime}$ & $-59^{\circ} 50^{\prime} 59.77^{\prime \prime}$ & 119 & & & & \\
\hline & BDF-12 & & $-2^{\circ} 23^{\prime} 30.15^{\prime \prime}$ & $-59^{\circ} 51^{\prime} 10.87^{\prime \prime}$ & 110 & & & & \\
\hline & BDF-13 & & $-2^{\circ} 23^{\prime} 55.07^{\prime \prime}$ & $-59^{\circ} 54^{\prime} 49.18^{\prime \prime}$ & 153 & & & & \\
\hline & BDF-14 & & $-2^{\circ} 21^{\prime} 51.22^{\prime \prime}$ & $-59^{\circ} 58^{\prime} 27.25^{\prime \prime}$ & 137 & & & & \\
\hline & BNT-01 & & $-2^{\circ} 38^{\prime} 33.34^{\prime \prime}$ & $-60^{\circ} 09^{\prime} 27.44^{\prime \prime}$ & 118 & & & & \\
\hline & BNT-02 & & $-2^{\circ} 38^{\prime} 29.46^{\prime \prime}$ & $-60^{\circ} 09^{\prime} 1.66^{\prime \prime}$ & 119 & & & & \\
\hline & BNT-04 & & $-2^{\circ} 37^{\prime} 45.25^{\prime \prime}$ & $-60^{\circ} 09^{\prime} 15.05^{\prime \prime}$ & 117 & & & & \\
\hline & JAC-01 & & $-2^{\circ} 36^{\prime} 23.27^{\prime \prime}$ & $-60^{\circ} 12^{\prime} 23.53^{\prime \prime}$ & 90 & & & & \\
\hline & JAC-02 & & $-2^{\circ} 36^{\prime} 54.20^{\prime \prime}$ & $-60^{\circ} 11^{\prime} 46.58^{\prime \prime}$ & 101 & $20 \times 500$ & $\mathrm{TF}$ & 006/062 & 23 Sep 2003 \\
\hline \multirow[t]{5}{*}{ Sucusari } & SUC-01 & Peru & $-3^{\circ} 15^{\prime} 7.60^{\prime \prime}$ & $-72^{\circ} 54^{\prime} 26.77^{\prime \prime}$ & 123 & & & & \\
\hline & SUC-02 & & $-3^{\circ} 15^{\prime} 4.11^{\prime \prime}$ & $-72^{\circ} 54^{\prime} 12.94^{\prime \prime}$ & 128 & & & & \\
\hline & SUC-03 & & $-3^{\circ} 14^{\prime} 49.02^{\prime \prime}$ & $-72^{\circ} 55^{\prime} 20.76^{\prime \prime}$ & 101 & & & & \\
\hline & SUC-04 & & $-3^{\circ} 15^{\prime} 1.29^{\prime \prime}$ & $-72^{\circ} 53^{\prime} 31.51^{\prime \prime}$ & 125 & & & & \\
\hline & SUC-05 & & $-3^{\circ} 15^{\prime} 37.68^{\prime \prime}$ & $-72^{\circ} 53^{\prime} 58.02^{\prime \prime}$ & 129 & & & & \\
\hline \multirow[t]{7}{*}{ Tambopata } & TAM-01 & Peru & $-12^{\circ} 50^{\prime} 38.81^{\prime \prime}$ & $-69^{\circ} 17^{\prime} 18.18^{\prime \prime}$ & 211 & $100 \times 100$ & FAT 3 & 002/069 & 23 Aug 2001 \\
\hline & TAM-02 & & $-12^{\circ} 50^{\prime} 5.11^{\prime \prime}$ & $-69^{\circ} 17^{\prime} 9.89^{\prime \prime}$ & 214 & & FAT 3 & & \\
\hline & TAM-04 & & $-12^{\circ} 50^{\prime} 11.47^{\prime \prime}$ & $-69^{\circ} 16^{\prime} 42.61^{\prime \prime}$ & 211 & & SW & & \\
\hline & TAM-05 & & $-12^{\circ} 49^{\prime} 49.04^{\prime \prime}$ & $-69^{\circ} 16^{\prime} 13.92^{\prime \prime}$ & 210 & & $\mathrm{TF}$ & & \\
\hline & TAM-06 & & $-12^{\circ} 50^{\prime} 18.59^{\prime \prime}$ & $-69^{\circ} 17^{\prime} 45.65^{\prime \prime}$ & 194 & & FAT 3 & & \\
\hline & TAM-07 & & $-12^{\circ} 49^{\prime} 32.45^{\prime \prime}$ & $-69^{\circ} 15^{\prime} 39.72^{\prime \prime}$ & 227 & & $\mathrm{TF}$ & & \\
\hline & TAM-08 & & $-12^{\circ} 49^{\prime} 34.70^{\prime \prime}$ & $-69^{\circ} 16^{\prime} 9.95^{\prime \prime}$ & 220 & & $\mathrm{TF}$ & & \\
\hline
\end{tabular}

in the SPRING Geographic Information System (GIS) free software (Câmara et al., 1996) for image processing and spatial data integration. The projection used is geographic and WGS84 datum. The six Landsat/ETM+ spectral bands centred at $479 \mathrm{~nm}, 561 \mathrm{~nm}, 661 \mathrm{~nm}, 834 \mathrm{~nm}, 1650 \mathrm{~nm}$ and $2220 \mathrm{~nm}$ (bands 1 to 5 and 7) with $30 \mathrm{~m}$ spatial resolution were geographically rectified using the methodology suggested by Richards (1993). The image-to-image geomet- ric rectification was performed using the NASA GeoCover ${ }^{1}$ product, with $14.5 \mathrm{~m}$ spatial resolution. The root mean square error (RMSE) was less than two pixels and normally less than one, depending on the number of control points selected in each scene (mainly roads or rivers).

For the Tambopata site, an IKONOS satellite panchromatic image with $1 \mathrm{~m}$ spatial resolution acquired in 2001 was used as ancillary data to support the interpretation of the

\footnotetext{
${ }^{1}$ https://zulu.ssc.nasa.gov/mrsid
} 
Table 3. Land cover classes description.

\begin{tabular}{|c|c|c|c|}
\hline Land Cover Classes in this study & $\begin{array}{l}\text { Description based on field obser- } \\
\text { vations }\end{array}$ & $\begin{array}{l}\text { Description based on the texture } \\
\text { of the ETM+ Landsat images }\end{array}$ & $\begin{array}{l}\text { Description based on the "UN } \\
\text { Land Cover Classification } \\
\text { System"a }\end{array}$ \\
\hline Land use & $\begin{array}{l}\text { Bare soil, pasture areas, crop- } \\
\text { lands and roads }\end{array}$ & Bare soil & $\begin{array}{l}\text { Depending on the region/size of } \\
\text { the patches: } 1,3 \text { and } 4\end{array}$ \\
\hline Disturbed forest & $\begin{array}{l}\text { Disturbed forest, secondary for- } \\
\text { est and logging areas }\end{array}$ & $\begin{array}{l}\text { Texture of a more homogeneous } \\
\text { "canopy topography" than pri- } \\
\text { mary forests }\end{array}$ & 1 \\
\hline Clouds & & Cloud & 6 \\
\hline Cloud shade & & $\begin{array}{l}\text { Cloud shadow/dark patches close } \\
\text { to clouds formations }\end{array}$ & 6 \\
\hline Water & Rivers and water bodies & & 5 \\
\hline Terra Firme & $\begin{array}{l}\text { Typical Terra Firme area, with } \\
\text { the elevation data showed }\end{array}$ & $\begin{array}{l}\text { Texture similar all over the re- } \\
\text { gions }\end{array}$ & 1. Some patches in the valleys: 2 \\
\hline Terra Firme 2 & $\begin{array}{l}\text { Terra Firme forest; presence of } \\
\text { palm trees, with sandy soil }\end{array}$ & $\begin{array}{l}\text { Patches of forests with darker } \\
\text { spectral characteristics than the } \\
\text { Terra Firme forests (without ap- } \\
\text { plying any contrast in the im- } \\
\text { agery) }\end{array}$ & 1 \\
\hline Terra Firme 3 & $\begin{array}{l}\text { Terra Firme forests, presence of } \\
\text { palm trees, with sandy soil }\end{array}$ & $\begin{array}{l}\text { Patches of forest with spectral } \\
\text { texture between the Terra Firme } \\
\text { and Terra Firme } 2 \text { spectral tex- } \\
\text { tures }\end{array}$ & 1 \\
\hline $\begin{array}{l}\text { Forests over alluvial terrain, type } 1 \\
\text { (FAT 1) }\end{array}$ & $\begin{array}{l}\text { Forest physiognomy in sea- } \\
\text { sonal inundated area located in } \\
\text { Holocene /Pleistocene alluvial } \\
\text { formation }\end{array}$ & $\begin{array}{l}\text { Texture in the image presenting } \\
\text { a pattern of "vegetation lines" } \\
\text { closed to each other, suggesting } \\
\text { the shape of Paleo-rivers }\end{array}$ & 2 and 1 \\
\hline $\begin{array}{l}\text { Forests over alluvial terrain, type } 2 \\
\text { (FAT 2) }\end{array}$ & $\begin{array}{l}\text { Forest physiognomy without in- } \\
\text { undation periods also located } \\
\text { in Holocene /Pleistocene alluvial } \\
\text { formations }\end{array}$ & $\begin{array}{l}\text { Texture very similar from FAT } 1 \text {. } \\
\text { Visually is not possible to differ- } \\
\text { entiate from type } 1 \text {, but it does } \\
\text { separates using classification al- } \\
\text { gorithms }\end{array}$ & 1 \\
\hline $\begin{array}{l}\text { Forest over alluvial terrain, type } 3 \\
\text { (FAT 3) }\end{array}$ & $\begin{array}{l}\text { Forest physiognomy similar to } \\
\text { Terra Firme forests, abundant } \\
\text { palm trees and Heliconias in the } \\
\text { understory, and more open; lo- } \\
\text { cated in Holocene/Pleistocene al- } \\
\text { luvial formations, non-flooded }\end{array}$ & $\begin{array}{l}\text { Forest physiognomy with the } \\
\text { same spectral texture of Terra } \\
\text { Firme forests; however, it is pos- } \\
\text { sible to observe in the ETM+ } \\
\text { Landsat imagery Paleo-river for- } \\
\text { mation }\end{array}$ & 1 \\
\hline $\begin{array}{l}\text { Forests over alluvial terrain with low } \\
\text { density of individuals }\end{array}$ & & $\begin{array}{l}\text { Similar texture of FAT } 1 \text { and } \\
\text { FAT } 2 \text {, however it is visible in the } \\
\text { imagery patches of bare soil }\end{array}$ & 2 and 1 \\
\hline Bamboo & $\begin{array}{l}\text { Bamboo dominant vegetation } \\
\text { formation. }\end{array}$ & $\begin{array}{l}\text { Classification algorithms sepa- } \\
\text { rated the bamboo areas into two } \\
\text { types }\end{array}$ & 1 \\
\hline Heliconia & Dominance of Heliconia species & $\begin{array}{l}\text { Texture of FAT vegetation; in the } \\
\text { image composition } 543 \text { in RGB } \\
\text { channels, it shows softer green } \\
\text { colour, slightly purple }\end{array}$ & 2 and 1 \\
\hline Flooded area & Permanent flooded area & $\begin{array}{l}\text { Mixture of green vegetation with } \\
\text { water bodies }\end{array}$ & 2 \\
\hline Seasonally inundated & $\begin{array}{l}\text { Seasonally inundated area over } \\
\text { streams }\end{array}$ & $\begin{array}{l}\text { Homogeneous green texture } \\
\text { (RGB 543)in the valleys of } \\
\text { Central Amazonia }\end{array}$ & 2 and 1 \\
\hline
\end{tabular}

a UN Land Cover Classification System Classes: 1 - Closed to open ( $>15 \%$ ) broadleaved evergreen or semi-deciduous forest ( $>5 \mathrm{~m}$ ); 2 - Closed to open $(>15 \%)$ broadleaved forest regularly flooded (semi-permanently or temporarily) - Fresh or brackish water, 3 - Mosaic cropland (50-70\%)/vegetation (grassland/shrubland/forest) (20-50\%), 4 - bare areas, 5 - Water bodies, 6 - No data (burnt areas, clouds). 
classified image, such as the identification of palm tree areas, swamp limits and the bamboo dominated regions which are clearly identified in this image.

\subsection{Topographic data processing}

The topographic dataset used in this study is the Shuttle Radar Topography Mission (SRTM) version $2^{2}$, which generated a complete high-resolution digital topographic database, with $90 \mathrm{~m}$ spatial resolution. These data measure approximately the top of the canopy height and thus do not represent the actual ground elevation value (which will be approximately $30 \mathrm{~m}$ below SRTM elevation). To exclude outliers caused by water bodies from the analysis, we replaced them with the mean value of the neighboring pixels. The elevation data were then resampled to $30 \mathrm{~m}$ spatial resolution using a nearest neighbor algorithm, for the following step of data aggregation on the Landsat 7 ETM+ images.

\subsection{Generating the landscape maps}

For this study, a considerable effort was spent precisely locating the field plots. The field plots were firstly located in the images using the Global Position System (GPS) point data acquired during field campaigns by the authors and other investigators. The Tambopata and Caxiuanã plot limits were obtained by walking along the perimeter of the plots and acquiring several points with the GPS connected to an external antenna placed on a 5 meter height structure. The use of the GPS antenna improved the signal reception, providing a relative low spatial error of only 3-5 m. For the other areas, location points were taken at the corners of plots or at some place within the transect and were used in addition to the field information such as distances to other plots, field camps, rivers and roads to demarcate the plot area.

Based on the location of the field plots, a region of $10 \mathrm{~km} \times 10 \mathrm{~km}$ with the field plots located in the center was established for defining the "landscape" region to be mapped and analyzed. In the two areas where the field plots were located far from each other, larger areas were selected to include all the plots (the Jenaro Herrera landscape is $15 \mathrm{~km} \times 10 \mathrm{~km}$ and the Manaus landscape is $45 \mathrm{~km} \times 30 \mathrm{~km}$ ).

Due to limitations of classification algorithms, in this study we combined the use of two distinct algorithms, in order to detect and classify the higher number of forest physiognomies as possible. The assumption is that if there is a significant spectral difference among vegetation types, captured by the classification algorithm, then each vegetation class in the map will reflect a distinct physiognomy. Saturation of the remote sensing signal captured by the sensors combined with the heterogeneity of targets (canopy layer) can lead to the classification algorithms to have inadequate grouping of dissimilar forest type or group distinct vegetation types that present the same reflectance in one forest class. To

\footnotetext{
${ }^{2} \mathrm{ftp}: / / \mathrm{e} 0 \mathrm{srp} 01$ u.ecs.nasa.gov/srtm/version2
}

deal with the latter limitation of the remote sensing data, topographic data were used to further characterize this variability without introducing false detections, as differences in forest species composition and dynamics in plateaus are known to be different from valleys (Chambers et al., 2001).

The image classifications performed in this study were generated by using image segmentation coupled with a region-based algorithm that have previously been successfully applied for mapping purposes (Rodriguez $\mathrm{Yi}$ et al., 2000; Almeida Filho and Shimabukuro, 2002). The approach was based on a region-growing technique developed by Kai and Muller (1991) and a non-supervised classification algorithm based on clustering techniques, developed by Bins et al. (1993). When this classification algorithm did not effectively distinguish different forest physiognomies, we used another region-based algorithm that uses a similarity criterion for clustering the differences based on the image histogram (Câmara et al., 1996). The comparison of the performance of each algorithm is not part of this research.

One potential problem associated with automatically classified maps is the production of omission and commission errors due to spectral similarity among targets or algorithm limitations (Shlien and Smith, 1975; Fitzgerald and Lees, 1994; Stehman, 1997; Salovaara et al., 2005). Thus, in order to generate more clearly differentiated results, we performed a manual edit of the maps to correct for class confusion and to adjust the limits of the land cover classes.

The land cover classes defined in this study were generated based on the combination of 3 groups of dataset. The first one is the "UN Land Cover Classification System" (GLOBCOVER) (Bicheron et al., 2008), in order to have an international land cover type classification. The GLOBCOVER classification is based on a $300 \mathrm{~m}$ spatial resolution dataset. Secondly, for each class, a brief description of the texture in the ETM+/Landsat image ( $30 \mathrm{~m}$ spatial resolution) is presented in order to capture land cover formations not depicted in the UN Land Cover Classification System, due to the spatial resolution of the dataset. In addition, the inclusion of the textural description of the Landsat imagery can be a useful source of information for the remote sensing community and scientists exploring this tool o assess land cover in Amazonia. Finally, field observations are presented (Table 3). Amazonian rain forests have traditionally been divided into two major forest types: inundated forests (over alluvial terrain) and non-inundated forests (Terra Firme) (Salo et al., 1986; Tuomisto et al., 1994; de Grandi et al., 2000; Tuomisto et al., 2003).

The alluvial terrain formation is related to the genesis of the rivers from Andean sources, where tectonic perturbance of the fluvial system during the Tertiary and Quaternary occasioned the change of the rivers flow and direction, exposing a soil with different physical and chemical properties (Hoorn, 1994; Campbell et al., 2001). Therefore, forests over alluvial terrains (or Paleovarzeas) are forests physiognomies located on relatively recent soils. Interestingly, the forests over 

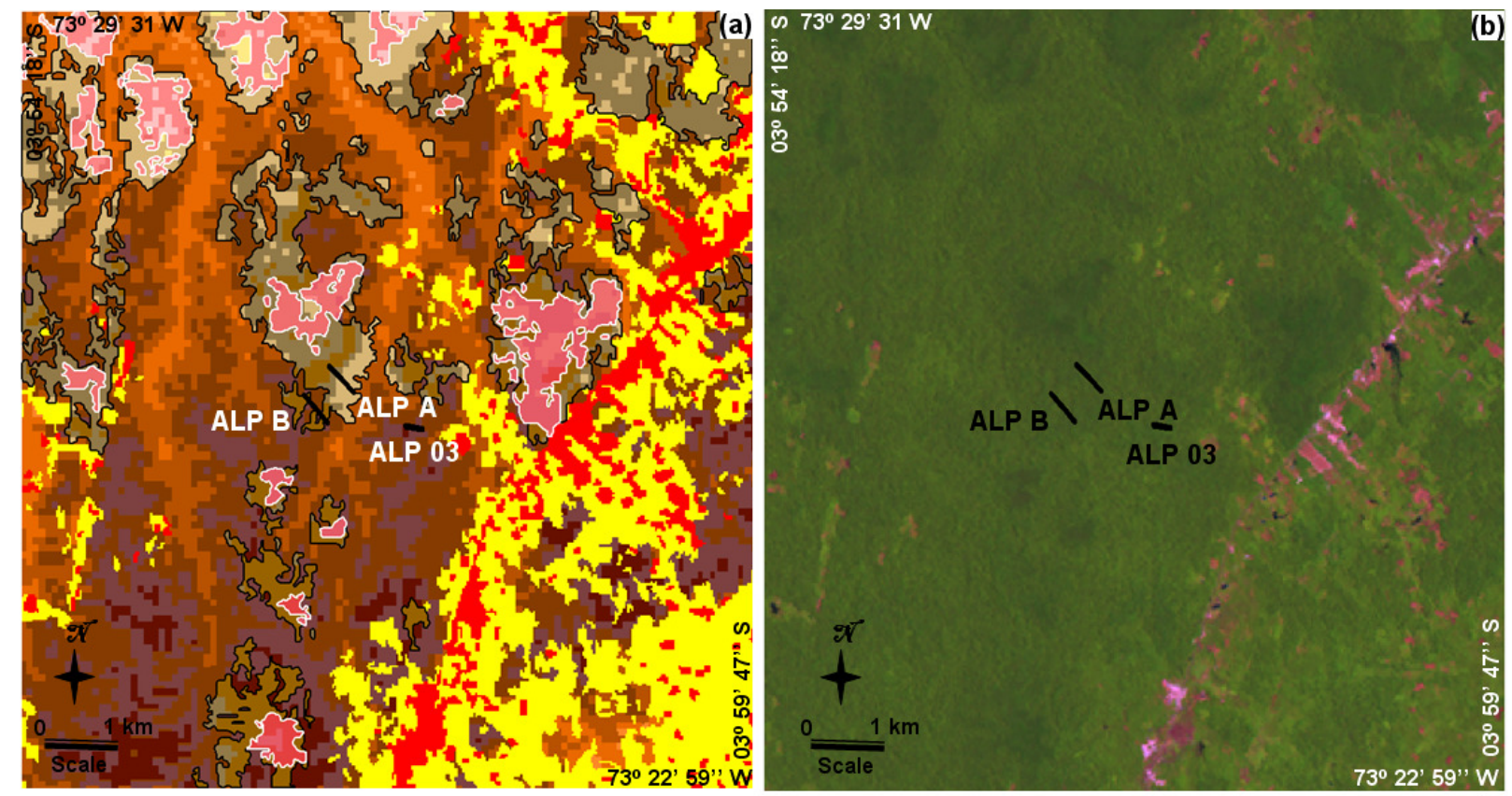

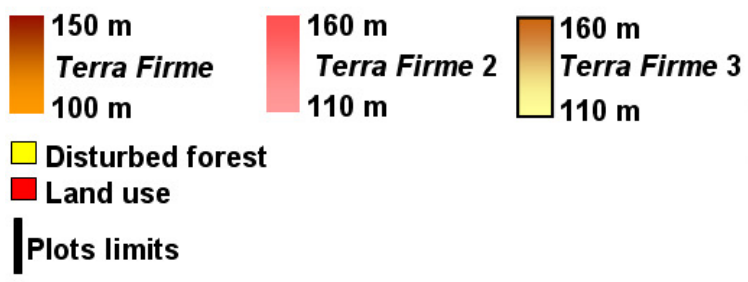

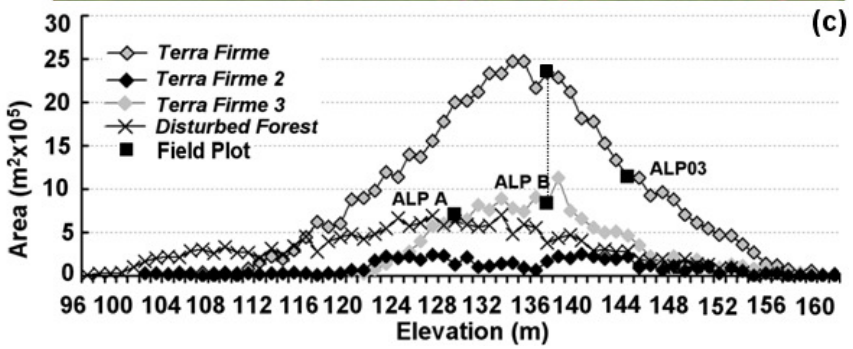

Fig. 2. Allpahuayo site: (a) Landscape map; (b) Landsat image for the field site (RGB channels in band 5, band 4 and band 3 ), the black rectangles represent the transects limits; (c) histogram of the elevation distribution per land cover class, with the field transects.

alluvial terrain, or forests over Paleovarzeas, are easily recognized in optical remote sensing imagery, unlike inundated forests.

The forests over alluvial terrain can also be further divided into two major groups: a) forests over alluvial terrain, that in the ETM+ Landsat image presents the same texture as Terra Firme forests, and $b$ ) forests over alluvial terrain that presents a texture in the ETM+ Landsat imagery of permanently or seasonally inundated areas. This differentiation in subtypes of forests over alluvial terrain based on the textural property of the satellite image is an effective way to characterize the heterogeneous mosaic of forest composition and structure in Terra Firme areas associated with differences in edaphic conditions (Table 3).

Terra Firme forests encompass a number of ecologically different forest types (Duque et al., 2003; Phillips et al., 2003; Malhi et al., 2004; Aragão et al., 2005). A large diversity of soils is found beneath Terra Firme forests in Amazonia (Quesada et al., 2009b), with Ferralsols, Acrisols, Leptosols, Cambisols and Plinthosols accounting for more than $80 \%$ of the soils types, and the forests' textural properties observed in remote sensing imagery are generally more homo- geneous than those forests over alluvial terrain, on Fluvisol soil type.

In addition to this main differentiation of Terra Firme and forests physiognomies over alluvial terrain, the SRTM data was used to further characterize the altitudinal range of each one of the vegetation classes depicted by the classification algorithms.

Map algebra were carried out by running a script written in Spatial Language for Algebra Geoprocessing (LEGAL) by using Boolean operations for integrating the forest physiognomy classes and the elevation layers.

\subsection{Wood productivity, wood specific density and above ground biomass (AGB) of the field plots in the land- scape context}

To evaluate which land cover types have been sampled in field inventories and the representativeness of these samples in the landscape mosaic we analyzed the proportional contribution of each land cover type and the spatial location of the field plots. 

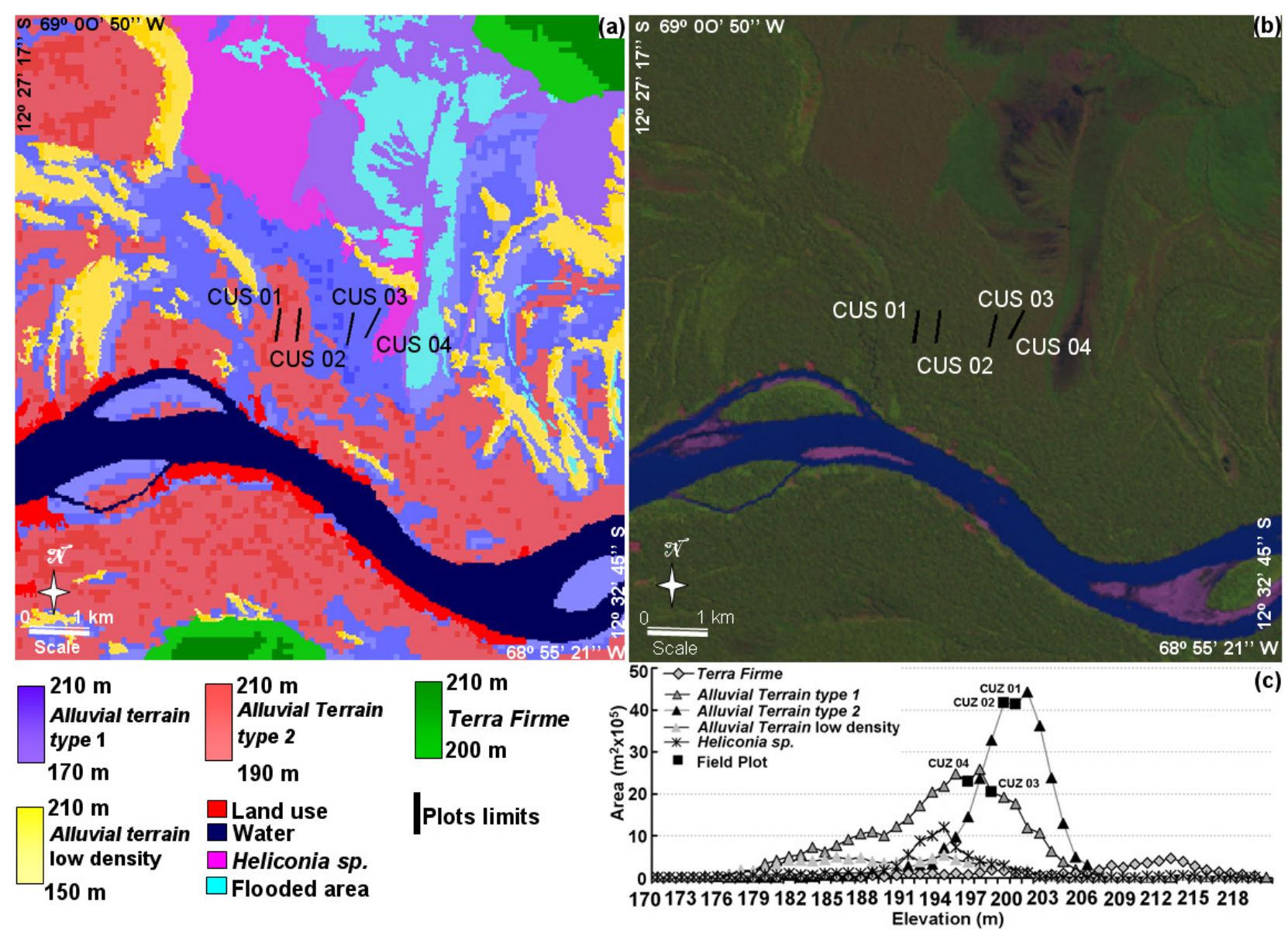

Fig. 3. Cuzco Amazonico site: (a) Landscape map; (b) Landsat image for the field site (RGB channels in band 5, band 4 and band 3), the black rectangles represent the transects limits; (c) histogram of the elevation distribution per land cover class, with the field transects.

The objective of this study was to assess the representativeness of forest properties of the sample plots in relation to the wider landscape. This was done by assigning a measured value of forest parameters to each forest class mapped in the remote sensing images, and then scaling to the landscape by weighting according to the area covered by each forest class. The weighted analysis was carried out only on sites with field measurements in more than one forest physiognomy (Allpahuayo, Cuzco Amazonico, Jenaro Herrera and Tambopata). In general, most of the field plots are located on Terra Firme sites or in Paleovarzea sites. Therefore we assess bias in sampling of the Terra Firme and alluvial terrain forests formations, not of the entire landscape (Table 2). In Allpahuayo, two types of Terra Firme forest were identified, and in Cuzco Amazonico, Jenaro Herrera and Tambopata, three types of vegetation formation over Paleovarzea were characterized. We use the relative area within the landscape of the physiognomies that characterizes the plots within a site to calculate a weighted average for the three biophysical variables. Vegetation physiognomies where no field data was available were not considered for the calculation. This was then compared with the forest properties obtained by simple, non-weighted average across the forest plot data. Any significant discrepancies between weighted and un-weighted values would indicate a degree of landscape bias. The forest variables assessed were the updated estimates of above ground wood productivity (Malhi et al., 2004), wood specific density (Baker et al., 2004b) and above ground biomass (Malhi et al., 2006). The first census data is from 1981 (Manaus site), and the most recent ones are from 2006 (Jenaro Herrera site). As the time interval and the total number of years monitored between the forest census can affect the above ground wood productivity estimates, two rules were applied for calculating the final values: a) the 2005 year forest census was not taken into account, as it was an anomalous dry year and there was an increase in trees mortality (Phillips et al., 2009), and b) a time-weighted procedure (multiplying the number of years in the time-interval by the wood productivity for that interval and dived the result by the length of the interval) for calculating the final estimates was used. 
Table 4. Detailed site parameters. Mean values of wood productivity wood density and above ground biomass updated from Baker et al. (2004a), Malhi et al. (2004, 2006). Forest censuses are pre-2005 year, except for the following plots: JEN 10, JEN 11, SUC 03 SUC 04, SUC 05, CAX 06. Mean values/Weighted mean values presented with \pm one standard error.

\begin{tabular}{|c|c|c|c|c|}
\hline Site & Field plot & $\begin{array}{l}\text { Mean Productivity } \\
\left(\mathrm{Mg} \mathrm{C} \mathrm{ha}^{-1} \mathrm{y}^{-1}\right)\end{array}$ & $\begin{array}{l}\text { Mean Density } \\
\qquad\left(\mathrm{g} \mathrm{cm}^{-3}\right)\end{array}$ & $\begin{array}{l}\text { Mean Biomass } \\
\left(\mathrm{Mg} \mathrm{DW} \mathrm{ha}^{-1}\right)\end{array}$ \\
\hline \multirow{5}{*}{ Allpahuayo } & ALP-03 & 2.00 & 0.66 & 265 \\
\hline & ALP A & 1.45 & 0.64 & 225 \\
\hline & ALP B & 1.68 & 0.62 & 209 \\
\hline & Mean value & $1.716( \pm 0.19)$ & $0.64( \pm 0.01)$ & $233( \pm 20)$ \\
\hline & Weighted mean value & 1.90 & 0.65 & 254 \\
\hline \multirow{6}{*}{ Cuzco Amazonico } & CUZ-01 & 1.91 & 0.55 & 262 \\
\hline & CUZ-02 & 2.10 & 0.52 & 225 \\
\hline & CUZ-03 & 2.15 & 0.55 & 231 \\
\hline & CUZ-04 & 3.14 & 0.58 & 280 \\
\hline & Mean value & $2.32( \pm 0.31)$ & $0.55( \pm 0.01)$ & $250( \pm 15)$ \\
\hline & Weighted mean value & 2.34 & 0.55 & 250 \\
\hline \multirow{8}{*}{ Jenaro Herrera } & JEN-03 & 2.55 & & 257 \\
\hline & JEN-06 & 2.72 & & 269 \\
\hline & JEN-09 & 2.55 & & 279 \\
\hline & JEN-10 & 1.29 & & 233 \\
\hline & JEN-11 & 4.07 & 0.67 & 295 \\
\hline & JEN-12 & 0.59 & 0.67 & 266 \\
\hline & Mean value & $2.29( \pm 0.54)$ & 0.67 & $267( \pm 9)$ \\
\hline & Weighted mean value & 2.47 & & 275 \\
\hline \multirow{6}{*}{ Sucusari } & SUC-01 & 3.53 & 0.60 & 287 \\
\hline & SUC-02 & 4.11 & 0.61 & 284 \\
\hline & SUC-03 & 2.10 & 0.70 & 322 \\
\hline & SUC-04 & 3.33 & 0.62 & 298 \\
\hline & SUC-05 & 2.93 & 0.61 & 287 \\
\hline & Mean value & $3.2( \pm 0.37)$ & $0.63( \pm 0.01)$ & $296( \pm 7)$ \\
\hline \multirow{9}{*}{ Tambopata } & TAM-01 & 2.75 & 0.51 & 235 \\
\hline & TAM-02 & 2.16 & 0.53 & 245 \\
\hline & TAM-04 & 2.98 & 0.61 & 290 \\
\hline & TAM-05 & 2.47 & 0.61 & 250 \\
\hline & TAM-06 & 1.70 & 0.49 & 255 \\
\hline & TAM-07 & 2.79 & 0.61 & 260 \\
\hline & TAM-08 & 1.81 & 0.58 & 219 \\
\hline & Mean value & $2.38( \pm 0.20)$ & $0.56( \pm 0.02)$ & $251( \pm 9)$ \\
\hline & Weighted mean value & $2.26( \pm 0.67)$ & $0.52( \pm 0.15)$ & $248( \pm 75)$ \\
\hline \multirow{17}{*}{ Manaus } & BDF-01 & 2.40 & 0.72 & 289 \\
\hline & BDF-03 & 2.20 & 0.66 & 358 \\
\hline & BDF-04 & 1.90 & 0.67 & 277 \\
\hline & BDF-05 & 2.24 & 0.69 & 322 \\
\hline & BDF-06 & 2.28 & 0.68 & 306 \\
\hline & BDF-09 & 2.39 & 0.71 & 405 \\
\hline & BDF-10 & 2.39 & 0.70 & 328 \\
\hline & BDF-11 & 1.16 & 0.70 & 395 \\
\hline & BDF-12 & 2.17 & 0.70 & 380 \\
\hline & BDF-13 & 1.73 & 0.71 & 365 \\
\hline & BDF-14 & 2.31 & 0.71 & 406 \\
\hline & BNT-01 & 1.26 & 0.69 & 376 \\
\hline & BNT-02 & 1.32 & 0.70 & 398 \\
\hline & BNT-04 & 2.15 & 0.71 & 337 \\
\hline & JAC-01 & 2.21 & 0.67 & 302 \\
\hline & JAC-02 & 2.02 & 0.68 & 292 \\
\hline & Mean value & $2.01( \pm 0.16)$ & $0.70( \pm 0.00)$ & $346( \pm 12)$ \\
\hline \multirow{5}{*}{ Caxiuanã } & CAX-01 & 1.39 & 0.73 & 394 \\
\hline & CAX-02 & 2.88 & 0.71 & 376 \\
\hline & CAX-06 & 0.49 & 0.71 & 416 \\
\hline & TEC-02 & 0.30 & 0.74 & 446 \\
\hline & Mean value & $1.27( \pm 0.68)$ & $0.73( \pm 0.00)$ & $408( \pm 17)$ \\
\hline
\end{tabular}




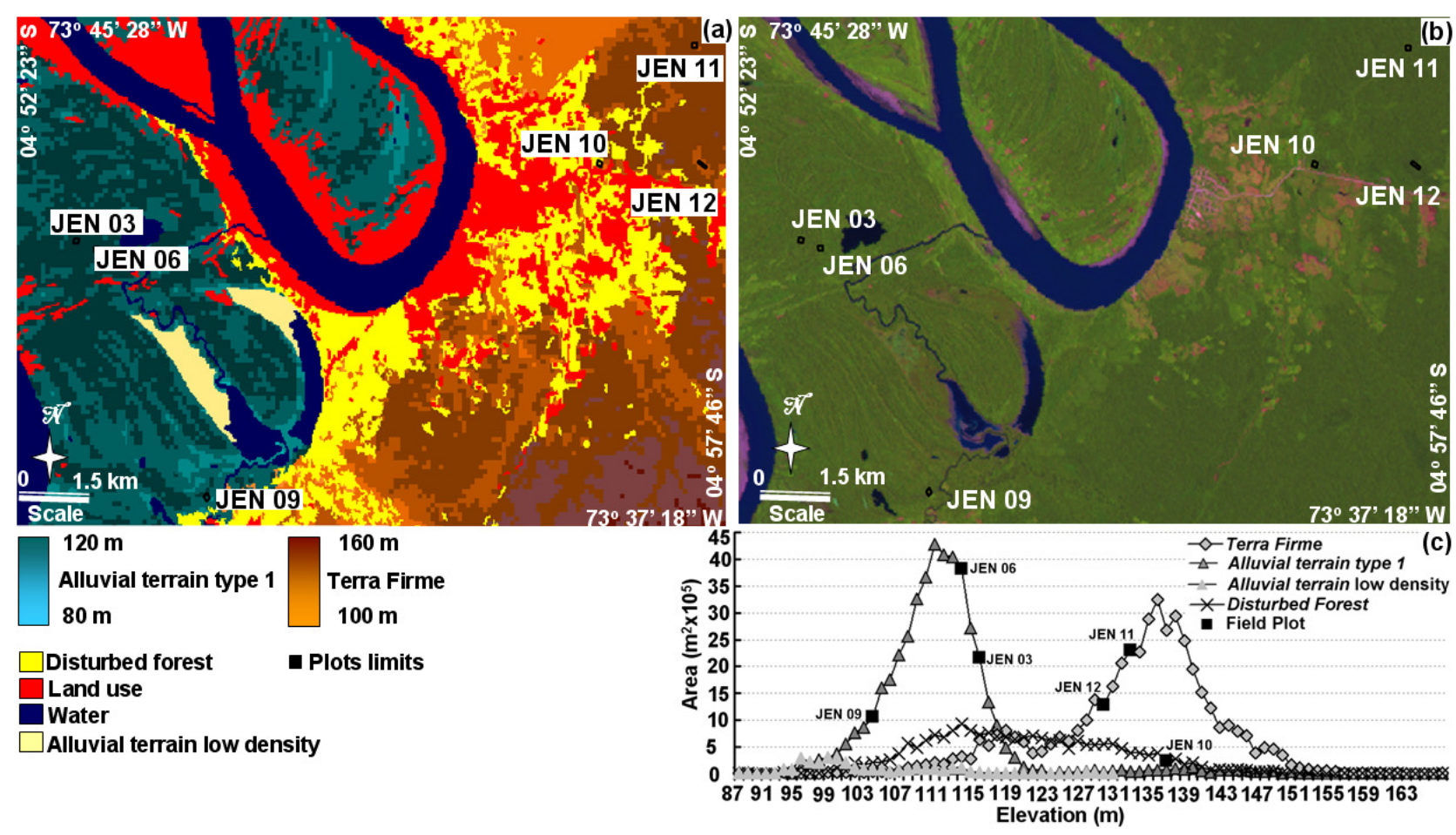

Fig. 4. Jenaro Herrera site: (a) Landscape map; (b) Landsat image for the field site (RGB channels in band 5, band 4 and band 3), the black rectangles represent the transect limits; (c) histogram of the elevation distribution per land cover class, with the field transects.

\section{Results}

\subsection{Landscape maps and field plot representativeness}

\subsubsection{Allpahuayo}

The Allpahuayo "landscape" map has 5\% of the total area covered by land use (roads, agriculture, pastures, villages), $25 \%$ covered by disturbed forest and $70 \%$ classified as Terra Firme (Fig. 2a, b). Within the Terra Firme forest class, the classification algorithms detected three spectrally distinct Terra Firme forest types (Table 3), here denominated Terra Firme 1, Terra Firme 2 and Terra Firme 3 (73\%, 6\% and $21 \%$, respectively). These three Terra Firme forest types occur in the same elevation range, varying from about $96 \mathrm{~m}$ to $166 \mathrm{~m}$ (Fig. 2c).

The characteristics of the three sample plots in Allpahuayo are described in Table 4. The ALP A and ALP B plots are transects that crosses both sandy and clay soils (Quesada et al., 2009b); however only the area around plot B was classified by the algorithms as picking up this variability. Based on the field descriptions of these two plots, it appears that the Terra Firme 2 and Terra Firme 3 classes are related to sandy soils, while Terra Firme 1 class reflects the forests on clay soil. The biophysical parameters also support this approach: ALP-03 has higher above-ground biomass and wood density than ALP A and ALP B. However ALP-03 has higher wood productivity, exhibiting more dynamism than expected. The field plots are representative of two of the identified forest types (Terra Firme and Terra Firme 3) covering 93\% of the natural landscape units mapped in this study.

Application of an area-weighted approach results in the mean value of wood productivity, wood specific density and above ground biomass being $10 \%, 1.5 \%$ and $8.2 \%$ higher than with the simple mean (Table 4).

\subsubsection{Cuzco Amazonico}

The Cuzco Amazonico landscape is located in a predominantly alluvial region in the vicinity of the Madre de Dios River, where the Cambisol soil type dominates. It has $2 \%$ of the area classified as land use, $10 \%$ of the area is covered by rivers and $6 \%$ is flooded area. Excluding these areas, there are four spectrally different forest physiognomies detected by the algorithms (Fig. 3a, b). Terra Firme forests are located in northern and southern extremes of the Landscape map, representing 5\% of the area. The forest over alluvial terrain (FAT) type 1 (occasionally inundated region Table 3) represent $40 \%$ of the area, while the forest over alluvial terrain (FAT) type 2 (non inundated areas) covers $37 \%$ of the region. As would be expected, the FAT type 1 is located in lower areas (Fig. 3c). There is a homogeneous and spectrally distinct area covering $8 \%$ of the landscape characterized by Heliconia sp. mono-dominance previously verified in the field (T. R. Baker, personal communication). The last 


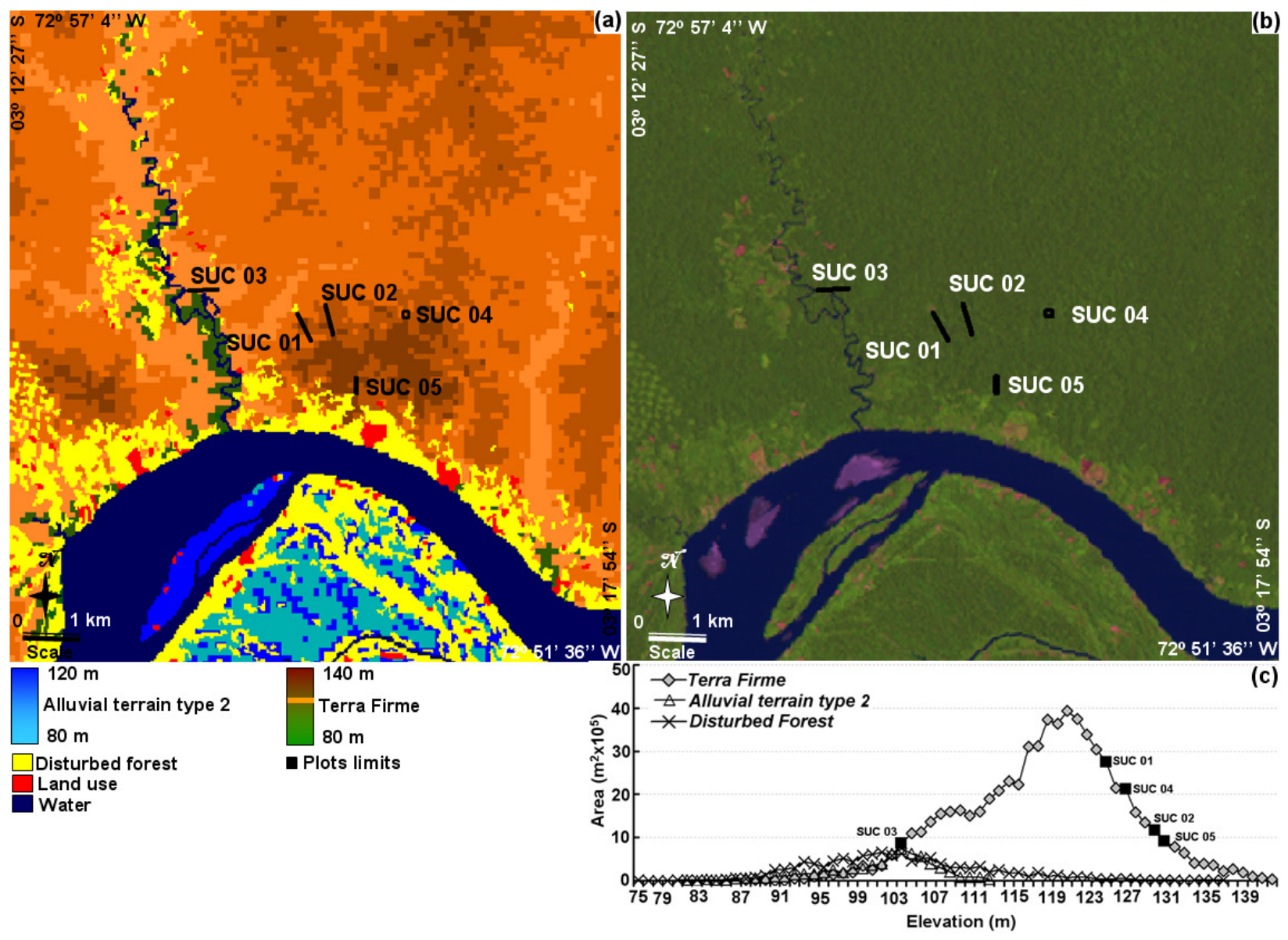

Fig. 5. Sucusari site: (a) Landscape map; (b) Landsat image for the field site (RGB channels in band 5 , band 4 and band 3 ), the black rectangles represent the transect limits; (c) histogram of the elevation distribution per land cover class, with the field transects.

forest class is a forest over alluvial terrain that presents a very low density of individuals with patches of bare soils evident, representing $10 \%$ of the area.

There are four field plots in Cuzco Amazonico region. The plots CUZ-01 and CUZ-02 are located in the non-flooded terrace and have a mean value of above ground biomass, wood productivity and wood density lower than the plots CUZ03 and CUZ-04, which present small sections that can get flooded (T. R. Baker, personal communication). Considering the primary forests land cover physiognomies, the field transects cover two of the five classes, covering $77 \%$ of the landscapes units mapped.

The weighted analysis showed minor changes in wood productivity (an increase of $0.8 \%$ ) and no changes in wood density and above ground biomass in relation to the unweighted mean (Table 4).

\subsubsection{Jenaro Herrera}

The landscape of Jenaro Herrera has $11 \%$ of its area covered by rivers and water bodies, $12 \%$ covered by disturbed forests and $15 \%$ covered by land use class. Excluding these classes, the primary forest physiognomies are composed of forests over alluvial terrain, type 1 , in the lower terrace (Table 3 ), representing $30 \%$ of the mapped area, and $40 \%$ covered by Terra Firme forests (Fig. 4).

There are six plots in this region, three of them in the $\mathrm{Pa}-$ leovarzea, located in different elevation (Fig. 4c), two plots located in the Terra Firme physiognomy, and one plot in the disturbed forest class. The mean value of above ground biomass is higher in the Terra Firme plots than in the plots over alluvial terrain, and the latter have mean AGB higher than the plot located in the disturbed forest (JEN-10). The JEN-10 plot location might be affected by errors on the geocorrection of the image and GPS measurements, as it is just in the limit of the disturbed forest class and Terra Firme class.

The weighted analysis showed an increase in $3 \%$ for above ground biomass and 7\% increase for the overall wood productivity for this site. Wood density was not evaluated due to the limited number of plots with this measurement (Table 4). Considering the forests physiognomies, the field plots in this region cover $81 \%$ of the landscape classes mapped for this site. 


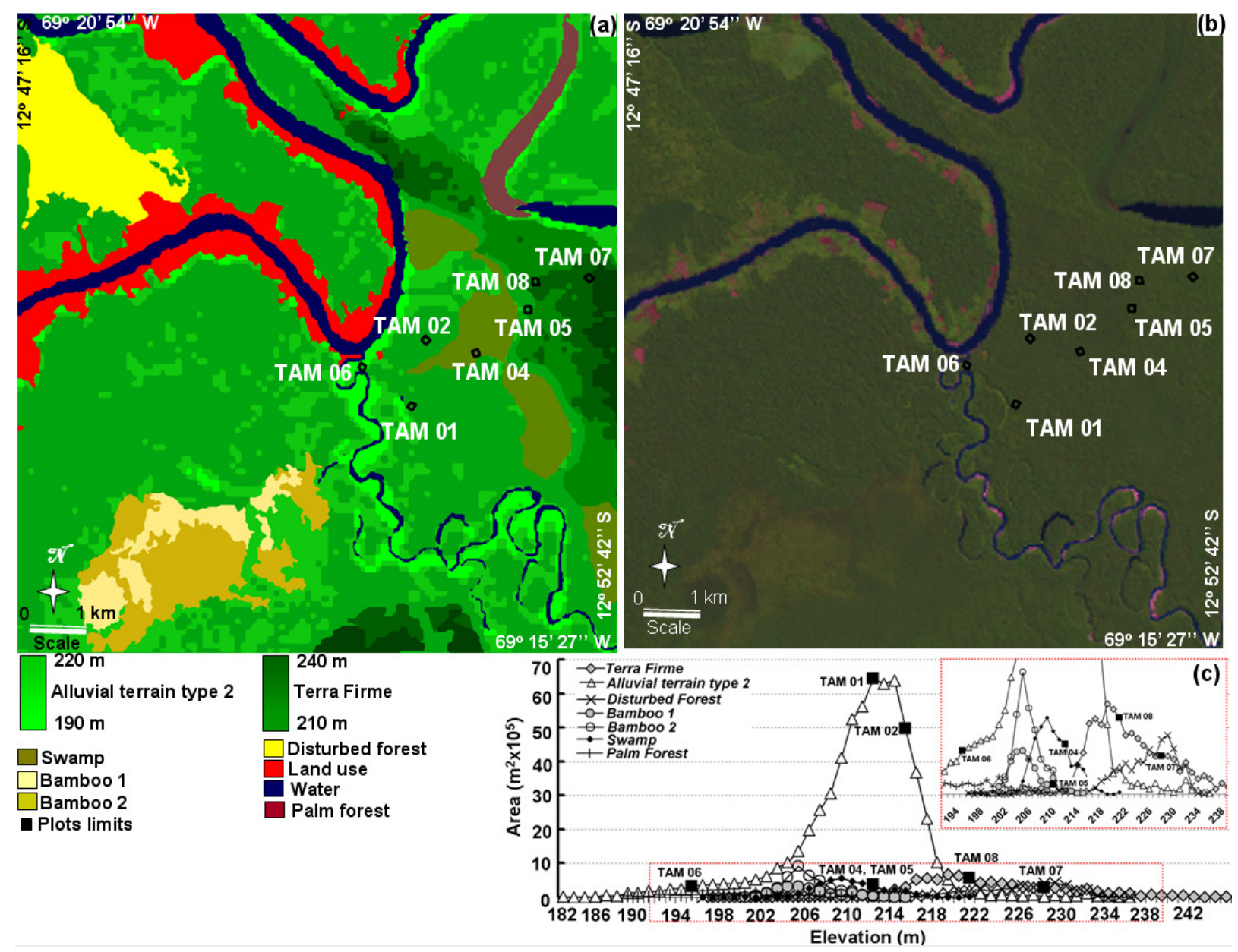

Fig. 6. Tambopata site: (a) Landscape map; (b) Landsat image for the field site (RGB channels in band 5, band 4 and band 3), the black rectangles represent the transect limits; (c) histogram of the elevation distribution per land cover class, with the field transects - the red rectangle in $x-y$-axis is presented in a zoom.

\subsubsection{Sucusari}

The Sucusari site has $12 \%$ of the mapped area covered by river and streams, $11 \%$ is disturbed forests and $1 \%$ is land use classes. The primary forests physiognomies are divided into Terra Firme class $(90 \%)$ and $10 \%$ covered by forests over alluvial terrain, type 2 (Table 3 ).

There are five plots in Sucusari, all located in the Terra Firme physiognomy, except plot SUC-03 which is a seasonally flooded forest (Fig. 5a, b). The Landsat/ETM+ image classification was not able to distinguish the seasonally flooded region from other regions; however, according to the field characterization of the plot SUC-03 and the elevation gradient of the region derived from the SRTM data, it is possible to distinguish two types of Terra Firme: the plateau and the river valley. Plot SUC-03 is located very close to a river and is seasonally inundated, suggesting a threshold around $110 \mathrm{~m}$ elevation to separate both physiognomies (Fig. 5c). This site has lower wood productivity and higher above ground biomass than the other plots in this site (Table 4).

The weighted analysis for the Sucusari was not carried out, as all the plots are located in the same forest physiognomy (as far as the Landsat/ETM+ analysis could distinguish).

\subsubsection{Tambopata}

In the Tambopata landscape map (Fig. 6), 7\% of the area corresponds to land use, $6 \%$ is covered by rivers and water bodies, and $4 \%$ is covered by disturbed forest. The non-disturbed vegetation type is divided into $10 \%$ of Terra Firme class and $75 \%$ of forests over alluvial terrain, type 3 (Table 3 ). Palm tree forests ( $1 \%$ of the forest area), Bamboo forest ( 2 types, representing $2 \%$ and $4 \%$ of the forest area) and the Swamp class (5\% of the area) were spectrally distinguishable and were characterized by using a combination of high resolution imagery (Palm tree forest and swamp), field data (swamp 

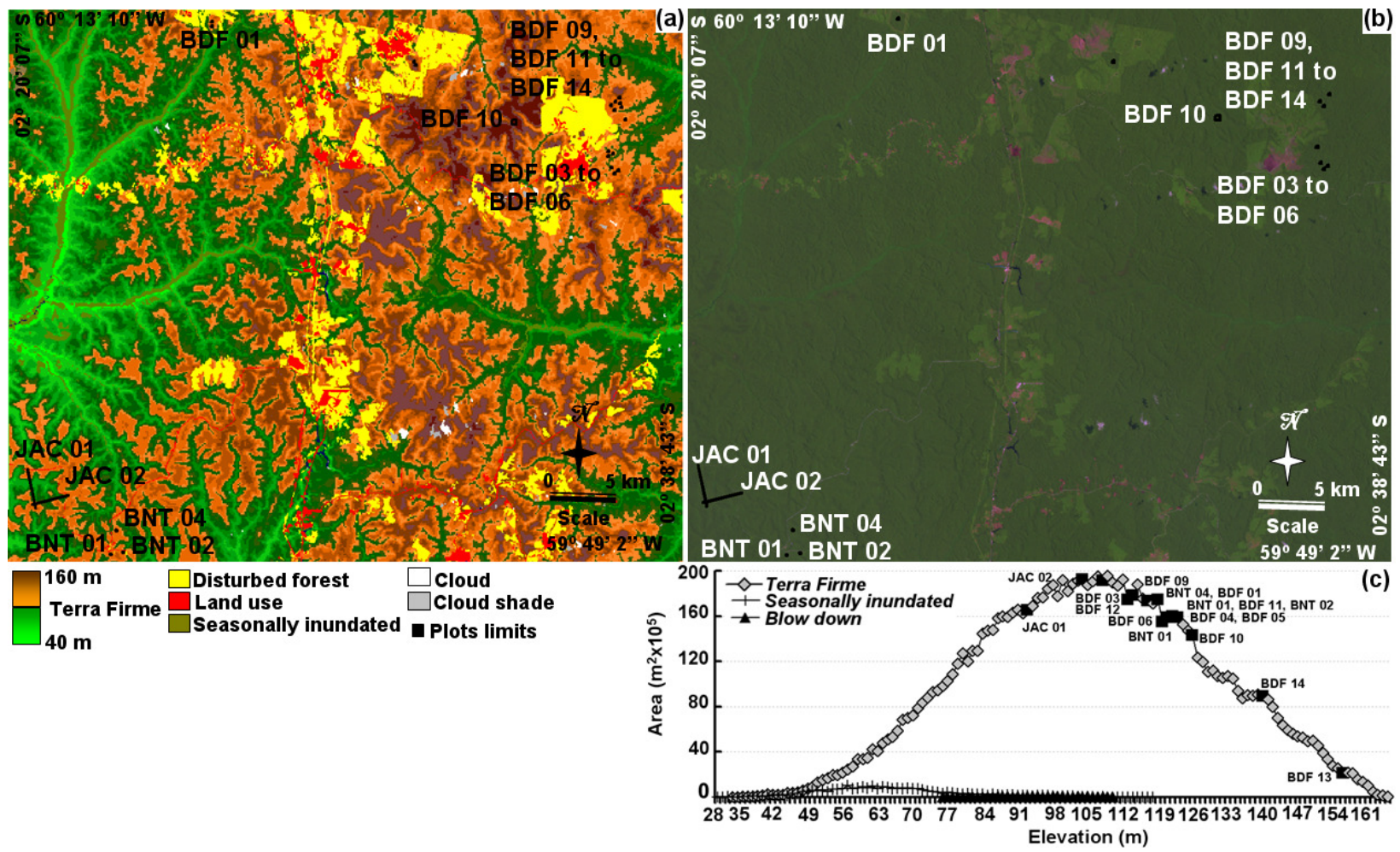

Fig. 7. Manaus site: (a) Landscape map; (b) Landsat image for the field site (RGB channels in band 5, band 4 and band 3 ), the black rectangles represent the transect limits; (c) histogram of the elevation distribution per land cover class, with the field transects.

area) and the literature (bamboo areas - in Foody and Hill, 1996).

There are seven plots in this site. The TAM-01, TAM02, and TAM-06 are located on a Pleistocene terrace, and this area was classified as forests over alluvial terrain, type 3 . The plots TAM-07 and TAM-08 are located in a Pleistocene terrace, and the vegetation type was classified as Terra Firme forest physiognomy. There is also one plot located in the swamp region, TAM-04, which presents higher above ground biomass and wood productivity then the other plots in this site. The Terra Firme plots have a mean wood density value higher than the forests over alluvial terrain, type 3 , in this site, but lower mean values of above ground biomass and wood productivity. Taking into account all the undisturbed forested physiognomies, the field plots are representative of $90 \%$ of the total landscape studied in this site.

The weighted analysis estimates a decrease in the values of the three biophysical parameters in relation to the published data, with $1.2 \%$ lower above ground biomass, $2.9 \%$ lower wood productivity and $3.5 \%$ lower wood density (Table 4 ).

\subsubsection{Manaus}

The landscape map generated for Central Amazonia (Manaus region) has less than $1 \%$ of the area covered by clouds, cloud shade and water bodies, $7 \%$ is covered by disturbed forests and $2 \%$ covered by land use. The undisturbed forests were classified as $98 \%$ of Terra Firme and 2\% alluvial. The Terra Firme class did not present spectral differentiation in the elevation range; however it is possible to assume that from $70 \mathrm{~m}$ to $80 \mathrm{~m}$ elevation there is a cut off and the landscape can be subdivided into river valleys and plateau (Fig. 7). Using this elevation range as a threshold, $17 \%$ of the Terra Firme forests in this landscape can be considered as river valley vegetation type.

There are 16 plots in the Manaus area (Table 4). They are located in the Terra Firme forest from $90 \mathrm{~m}$ to $160 \mathrm{~m}$ altitude, representing $98 \%$ of the area mapped. The plots JAC01 and JAC-02 are transect measuring $20 \times 2500 \mathrm{~m}$, ranging across plateau and lowland areas associated with streams valleys. This variation is reflected in the landscape map in Terra Firme class in association with the SRTM data. The vegetation structure (Higuchi et al., 1998) has been previously published for these plots. Soils vary from very clay-rich Ferralsols in the plateau to very sandy Podzols in the lowland (Quesada et al., 2009b). The two JAC plots are characterized by relatively lower above ground biomass and relative higher wood productivity in comparison to the other plots in this site.

In general, the Manaus field plots have been intensively studied and described in the literature evaluating AGB, wood productivity (Chambers et al., 2001; Clark et al., 2001) and 


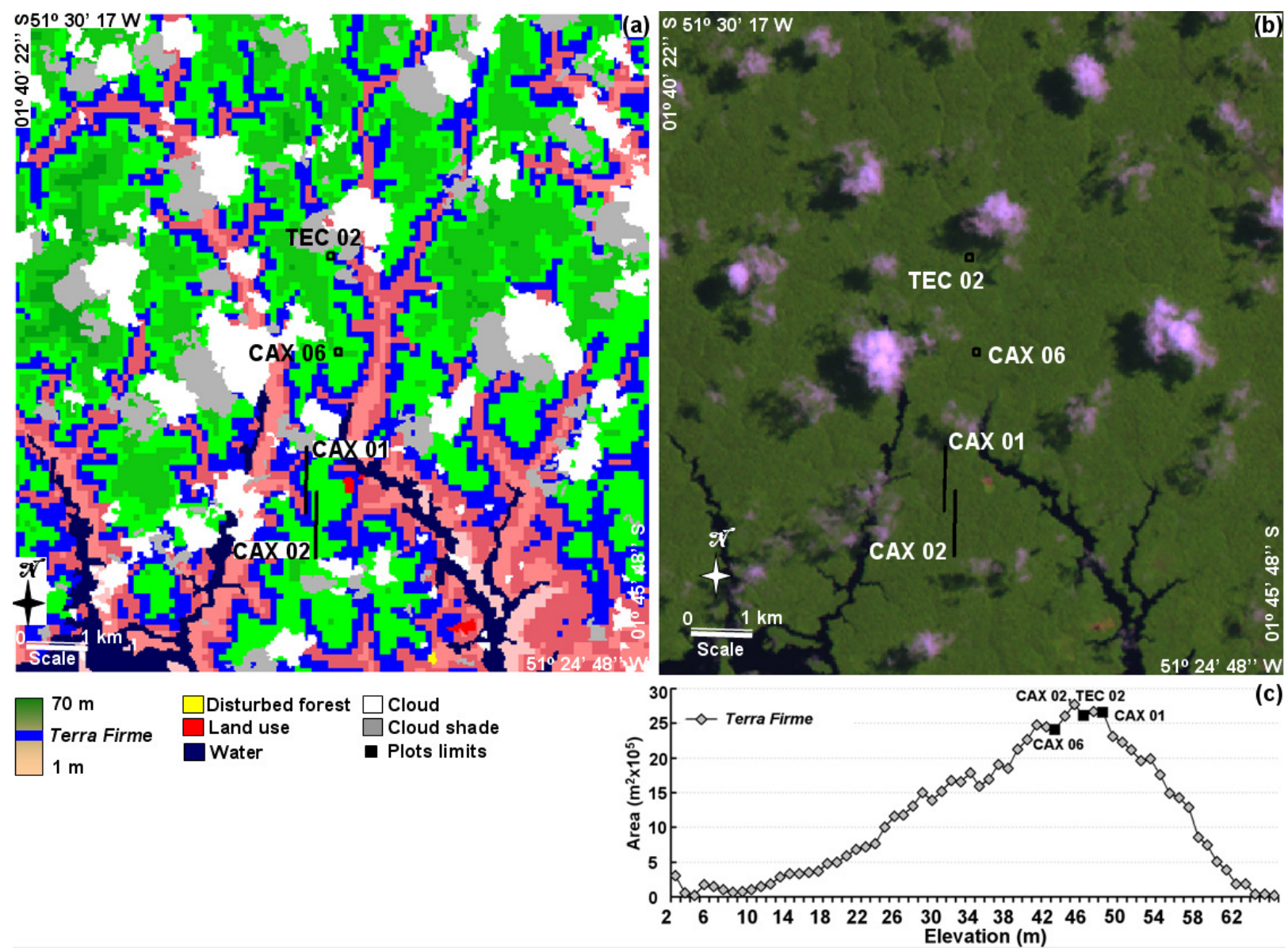

Fig. 8. Caxiuanã site: (a) Landscape map; (b) Landsat image for the field site (RGB channels in band 5, band 4 and band 3 ), the black rectangles represent the transect limits; (c) histogram of the elevation distribution per land cover class, with the field transects.

forest edge effects (Laurance et al., 1997; Nepstad et al., 1999). Considering the field sites that can be affected by edge effects (Laurance et al., 1997; Laurance et al., 1998), the plots BDF-01, BDF-10 and BDF-14 are located in less than $500 \mathrm{~m}$ from a disturbed or anthropogenic area. These plots show a mean wood productivity and biomass of $2.33 \mathrm{Mg} \mathrm{C}$ $\mathrm{ha}^{-1}$ year $^{-1}$ and $274 \mathrm{Mg} \mathrm{C}^{-1}$, respectively. The wood productivity value is higher than the mean value for the other plots in this site suggesting that forest disturbance affects these biophysical parameters.

The Manaus plots can be therefore considered to cover Terra Firme plateau and river valleys, as well as disturbed forests. The forest physiognomies not being sampled are the seasonally inundated areas, which represent less then $3 \%$ of the landscape.

\subsubsection{Caxiuanã}

The Caxiuanã landscape has two anthropogenic classes (land use and disturbed forest, covering less than $1 \%$ of the area), a river covering $4 \%$ of the landscape map and clouds and clouds shadows that covers $21 \%$ of the mapped area. The undisturbed forest is composed mainly by Terra Firme class (74\% of the total area) with homogeneous spectral response (Fig. 8). However, the Terra Firme forest can be subclassified into plateau and river valleys if a threshold around $30-40 \mathrm{~m}$ elevation is considered (Fig. 8a). In this case, $36 \%$ of the landscape region evaluated can be considered as river valley vegetation type.

In Caxiuanã we utilised four field plots: CAX-01, CAX02, CAX-06 and TEC-02 (Table 4). The transects CAX-01 and CAX-02 cover part of the elevation range, from $29 \mathrm{~m}$ to $35 \mathrm{~m}$. These two plots present higher wood productivity and lower above ground biomass than the other plots located in the plateau.

\subsection{Regional variation in wood productivity, wood spe- cific density and above ground biomass}

Wood productivity did not show a clear regional pattern from the south-western sites to the north-eastern sites (Fig. 9a), but wood density and above ground biomass mean values 


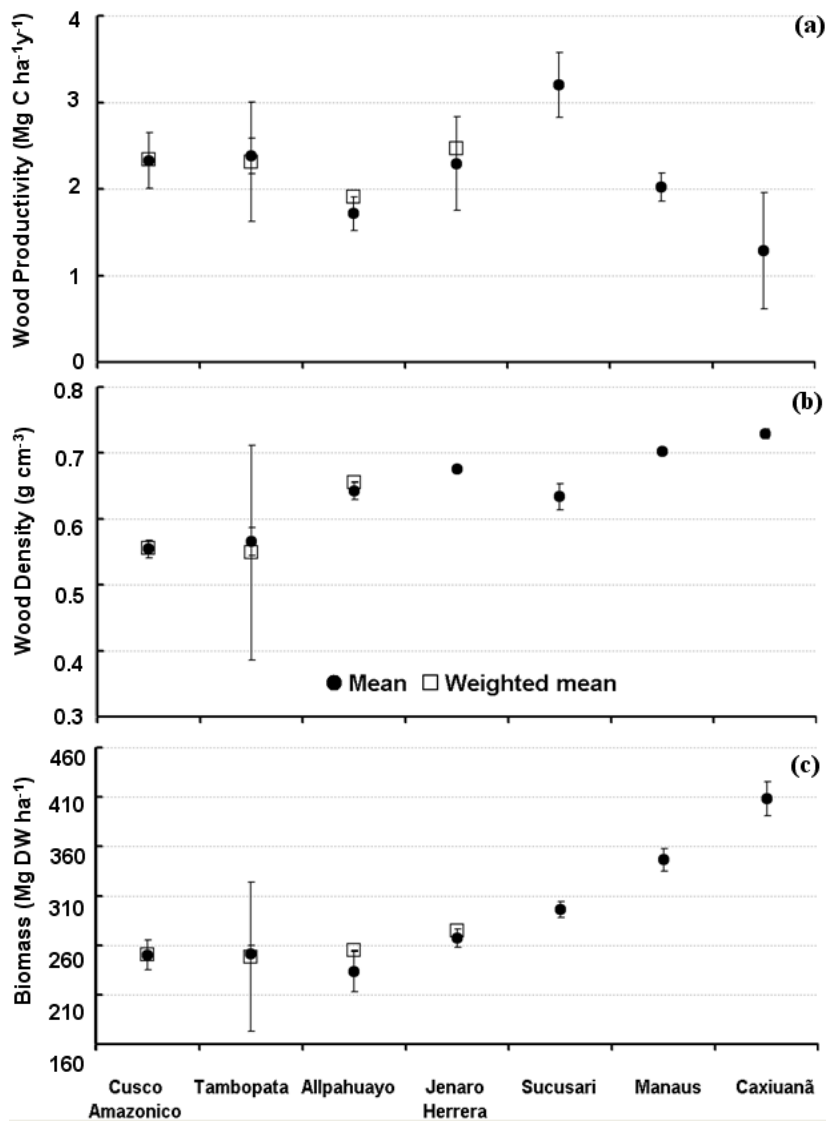

Fig. 9. Mean and weighted mean values evaluation per site: (a) Wood productivity, (b) wood density and (c) above ground biomass.

were higher in the north-east (Fig. 9b and c). These patterns did not change according to the result of the area weightedanalysis (Fig. 9).

In this study, the Peruvian plots were considered as western Amazonia sites, the Manaus plots in Brazil were considered central Amazonia site and the Caxiuanã plots were considered eastern Amazonia site for a macro-regional analysis. An evaluation of the plots located only in the Terra Firme physiognomy showed that the three variables are clearly distinguishable from western to eastern Amazonia (Fig. 10).

The variation in the spatial heterogeneity of the landscape observed in the forests over alluvial terrain is characterized by differences in texture observed in the remote sensing data that reflects differences in geomorphology, vegetation, soil chemical and physical characteristics and inundation pulse. The three types of forests located on Paleovarzeas classified in this study also reflect these differences. The physiognomy type 1, characteristic of Jenaro Herrera (plots 3, 6 and 9) and Cuzco Amazonico (plots 03 and 04), is composed of younger soils, probably from the Holocene period. This physiognomy is characterized by higher above ground biomass and is more productive than the other two types (Fig. 11). The type 2

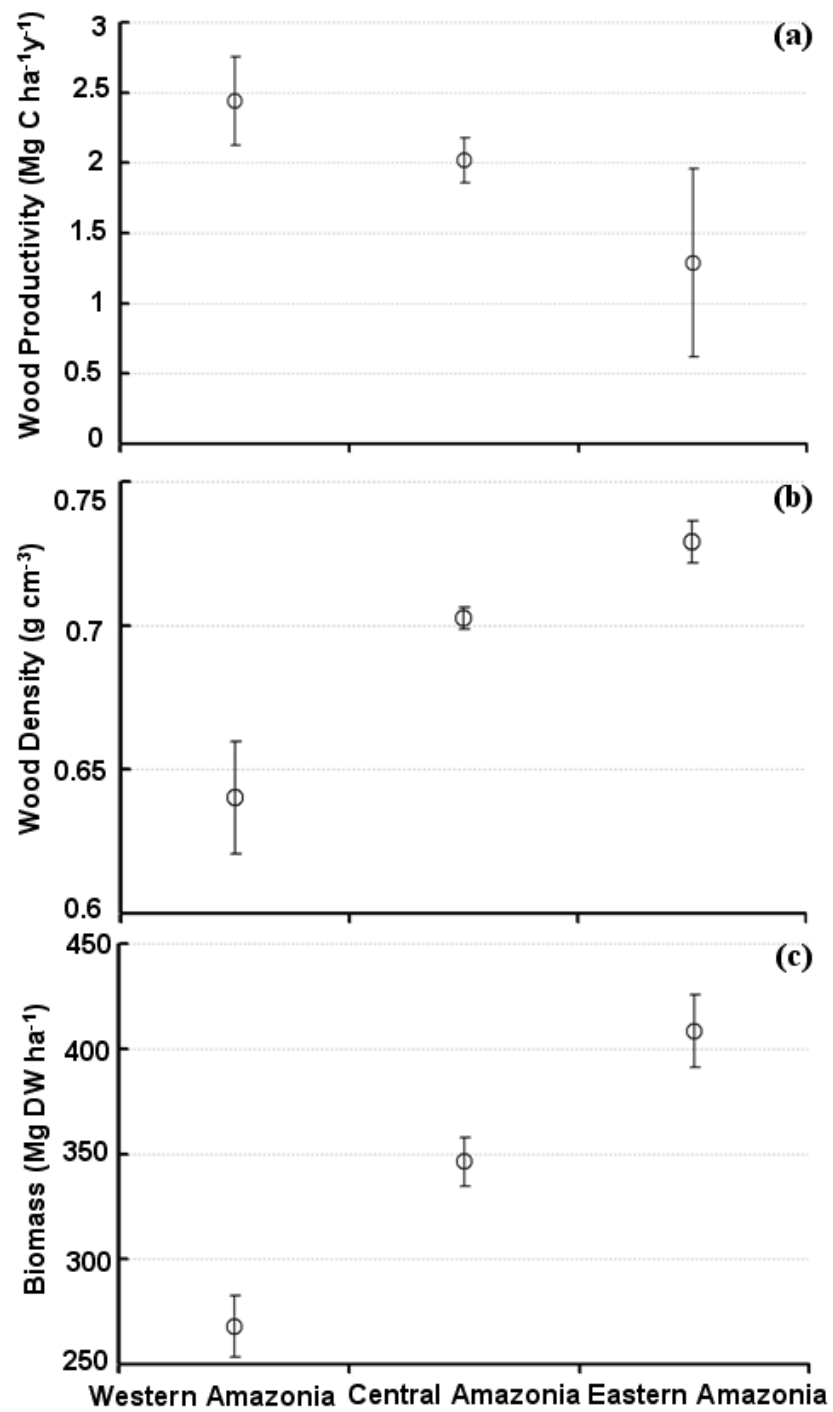

Fig. 10. Macro-regional variability of (a) Wood productivity, (b) wood density and (c) above ground biomass mean values $( \pm$ one standard error) for the plots located in the Terra Firme physiognomy.

physiognomy is also located in the same geomorphological area as the type one (Cuzco Amazonico, plots 01 and 02), but without the potential for inundation. It presents lower mean values for the three parameters evaluated. The forests over alluvial terrain, type 3 , is located in older terraces, assumed to be from the Pleistocene, and presents higher values of above ground biomass and wood productivity than type 2 and lower values of those parameters than type 1 . 


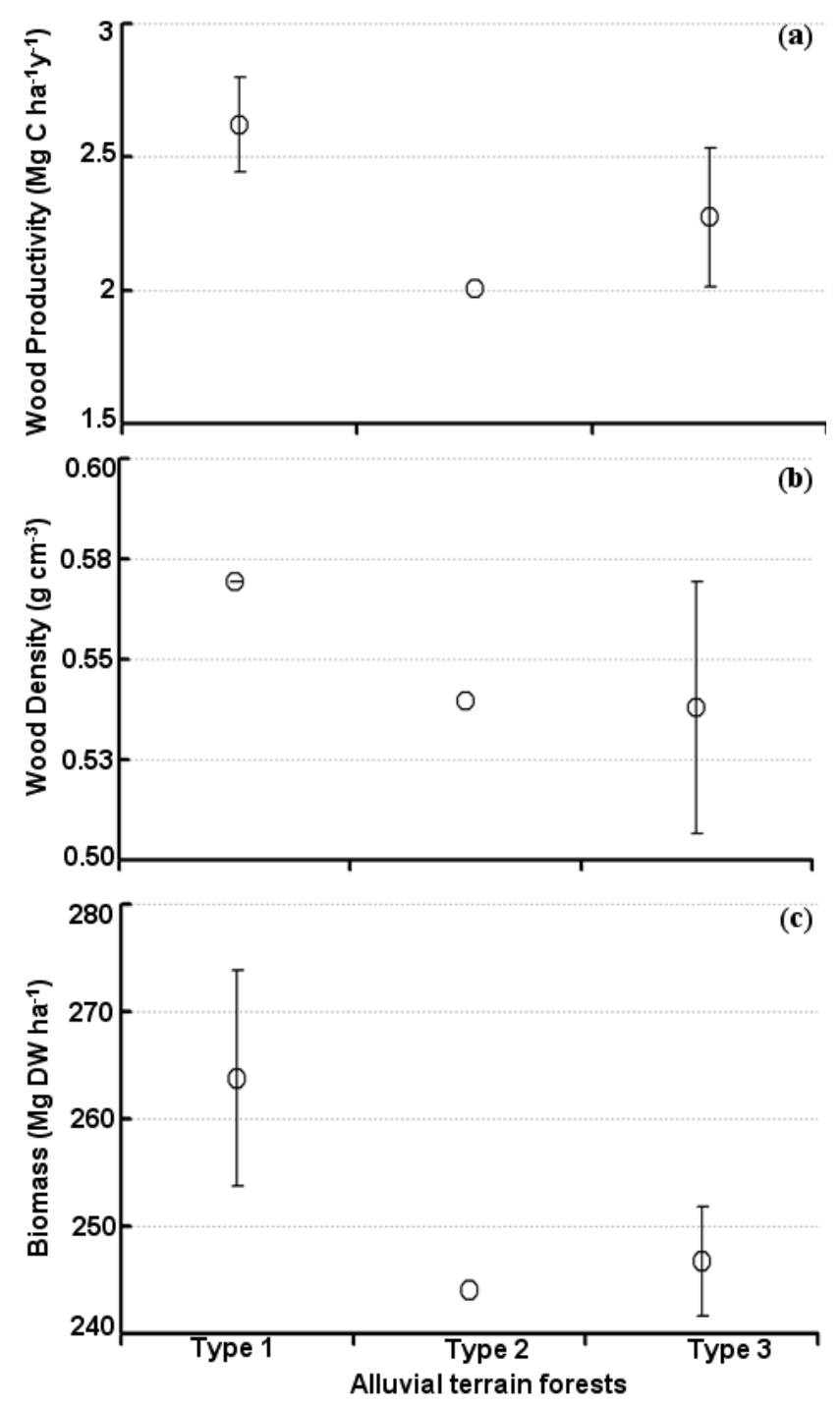

Fig. 11. Variability within the alluvial terrain forests physiognomy mean values with \pm one standard error: (a) Wood productivity, (b) wood density, (c) above ground biomass.

\section{Discussion}

\subsection{Landscape mapping}

Remote sensing data can be an important source of information on the spatial distribution of different vegetation physiognomies in tropical forests. In this study, we distinguished three types of Terra Firme forests, three types of forests over Paleovarzeas (alluvial terrain), swamp areas, palm forest, two types of bamboo dominated forests and seasonally inundated areas.

Salovaara et al. (2004) produced a map based on field work data with four main forest classes separated by floristic characteristics in northeastern Peruvian Amazonia. The same authors then investigated the possibility of aggregating a Land-

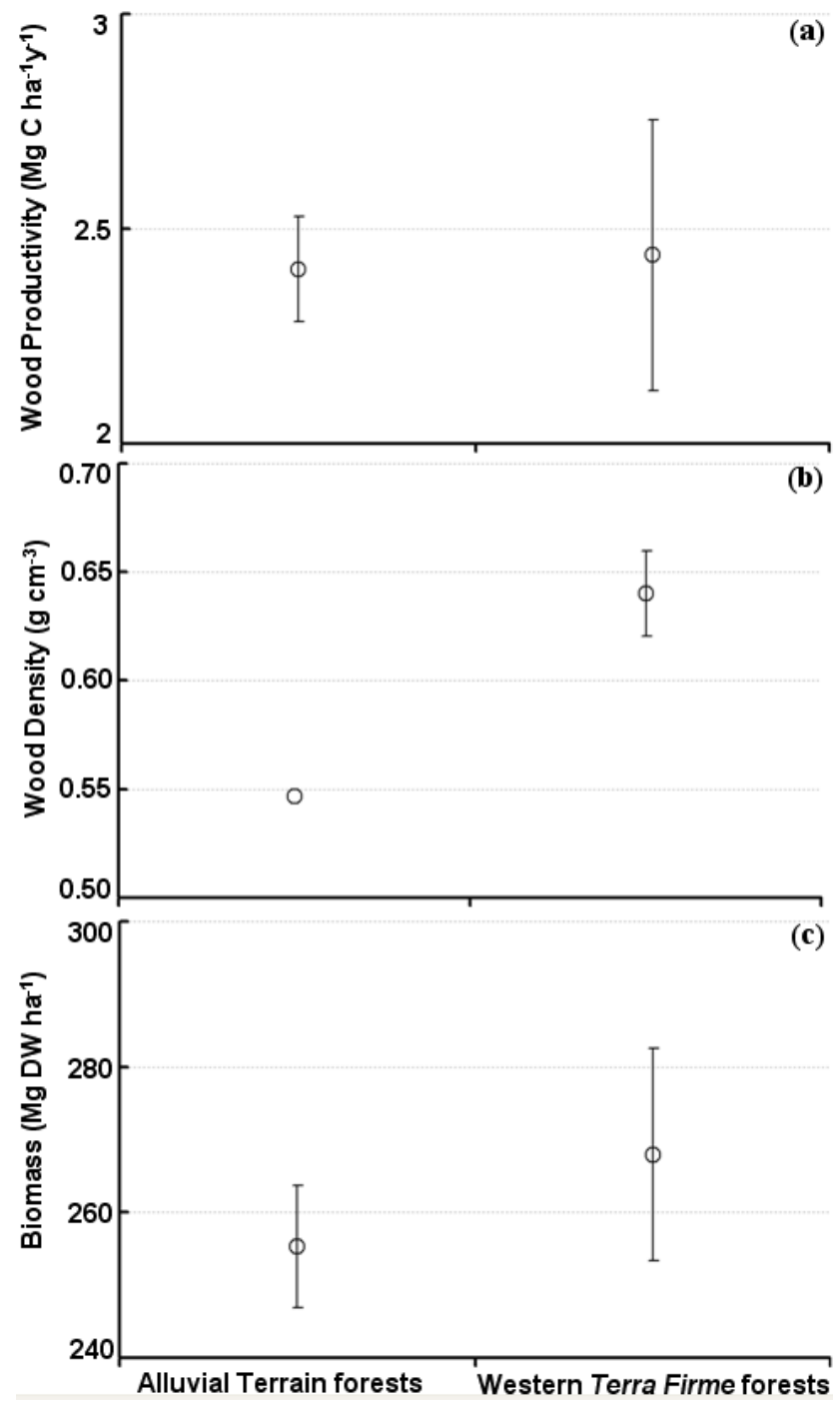

Fig. 12. Comparison of the forest variables in alluvial terrain with the Western Terra Firme sites. (a) Wood productivity, (b) wood density and (c) above ground biomass $( \pm)$ one standard error.

sat/ETM+ image with altimetry data derived from SRTM to achieve the same results as found for the map solely based on field data (Salovaara et al., 2005). They succeeded in separating inundated areas from Terra Firme; however Pebas formation forests and intermediate Terra Firme forests were misclassified by the algorithms. Due to the characteristics of the forest types evaluated in this study, forests over alluvial terrain (inundated and non-inundated forests) were generally successfully separated automatically from Terra Firme areas (with the exception of one site, Sucusari plot SUC-03). Moreover, in the Terra Firme forests in the Allpahuayo site, it was possible to automatically separate three Terra Firme sub-classes due to the presence of forests over sandy soil and regions with high palm tree density, a feature which is visually darker in the satellite image due to the higher proportion 
of canopy shade. Previous studies reported that sandy soil forests could not be automatically separated using satellite images due to limitations of the algorithms (Foody and Hill, 1996; Hill, 1999). At this site, the forest characteristics of the sandy soils appear to be sufficient distinct from those of the surrounding clay areas.

Foody and Hill (1996) have studied the Tambopata region on a larger geographic scale, and using automatic classification they were able to separate the swampy areas from the other land cover types (Bamboo and lowland forests). In spite of using different classification algorithms to Foody and Hill (1996), in this study we still expected that the swamp areas would produce a distinguishable spectral characteristic. However, this was not the case. One possible explanation for this lack of differentiation might be that the images in the two studies were acquired on different dates. Thus, it is probable that the water level may have been different; thereby changing the swamp's spectral properties and the ability to distinguish swamps from Terra Firme forests.

\subsection{Wood productivity, wood density and above ground biomass patterns across Amazonia}

Our results generally support previous findings about the regional variation in forest wood productivity, wood specific density and above ground biomass in Amazonia revealed by the RAINFOR network (Malhi et al., 2004; Phillips et al., 2004; Lewis et al., 2004; Baker et al., 2004a, b). The RAINFOR sites in this study have been used to demonstrate that forest productivity is higher in western Amazonia than the Central and Eastern regions. This pattern follows a gradient of soil structural and chemical composition and number of dry months (Quesada et al., 2009a). It has also been suggested that the absolute wood specific density value of the species declines with increasing soil fertility similarly for both trees and saplings/shrubs (Huston, 1980; Swaine and Becker, 1999), and that there is no robust relationship between soil fertility and wood specific density of tropical forest tree species (Wright, 1992; Clinebell et al., 1995). In this study, western Amazonia had the lowest mean value for wood specific density. Muller-Landau (2004) and Baker et al. (2004) reported higher wood specific density in nutrientpoor soils in central Amazonia and lower values in western Amazonia with richer soils, independent of rainfall, seasonality and temperature. However, it has been generally noted that within the RAINFOR sites, wood specific gravity varies widely among species and that within-species variations can also be significant (Patiño et al., 2009).

Nebel et al. (2001) found a significant relationship between forest productivity and biomass and the period of flooding in seasonally inundated forests. Therefore, as we showed that some of the RAINFOR plots are located in alluvial terrains, it might be expected that these sites could be driving the observed east-west variation (Fig. 12). For instance, within the Cuzco Amazonico site all four plots are characterized by forests over alluvial terrain. Similarly, Tambopata and Jenaro Herrera sites have the majority of their plots in Holocene alluvial terrains. Although very few of these plots located in forests over Paleovarzeas are seasonally flooded, the mean wood productivity of these sites is about the same as the Western Terra Firme sites, and the absolute mean value is higher than the mean values for all Terra Firme sites (Fig. 12a). It is pertinent to note that the seasonally flooded plots show a wide range of coarse wood productivities, possibly related to sediment loading and flooding period (Malhi et al., 2004).

A previous study quantifying the flooded forests in Central Amazonia estimated a total area of $187 \times 10^{3} \mathrm{~km}^{2}$ (Hess et al., 2003) - a substantial region with high importance for the carbon fluxes. Therefore, more studies on quantifying the dynamics of the flood plain forests would provide valuable and more accurate information on the variation of the amount of carbon stored in these areas and its dynamics. In their analysis of the RAINFOR plots, Baker et al. (2004b) found that ABG and stand-level wood specific gravity of the floodplain plots are structurally the same as the non-floodplain western Amazonian plots. Our results showed that there is a significant difference in wood density from forests located on more recent alluvial terrain sites and Western Terra Firme sites (Fig. 12b) but no significant difference in the above ground biomass (Fig. 12c).

\section{Conclusions}

In this paper we have precisely located many key RAINFOR plot clusters covering western, central and eastern Amazonia for a landscape evaluation of the representativeness of those plots and its implications for a apparent regional variation in forest biophysical parameters.

We conclude that the plots were generally representative of the forest physiognomies in the landscape in which they are located, and the forest parameters analysis supports the observed regional trends.

The landscape maps generated here can be used as a basis for defining different vegetation types to be sampled, and future work involving radar remote sensing data could be used in combination for improving of the capturing the forest structural parameters.

Acknowledgements. We thank the EU-funded PAN-AMAZONIA project for the training and field campaigns funds, the Coordenação de Aperfeiçoamento de Pessoal de Nível Superior (CAPES) for the PhD scholarship (BEX4018052) and Instituto Internacional de Educação do Brasil (BECA-B/2006/01/BDE/04) for the financial support. We also thank the RAINFOR network participants for their helpful comments and effort to better locate the field sites.

Edited by: J. Lloyd 


\section{References}

Almeida-Filho, R. and Shimabukuro, Y. E.: Digital processing of a Landsat-TM time series for mapping and monitoring degraded areas caused by independent gold miners, Roraima State, Brazilian Amazon, Rem. Sens. Environ., 79, 42-50, 2002.

Andreae, M. O., Jones, C. D., and Cox, P. M.: Strong present-day aerosol cooling implies a hot future, Nature, 435, 1187-1190, 2005.

Aragão, L. E. O. C., Shimabukuro, Y. E., Espírito-Santo, F. D. B., and Williams, M.: Landscape pattern and spatial variability of leaf area index in Eastern Amazonia, Forest. Ecol. Manag., 211, 240-256, 2005.

Aragão, L. E. O. C., Malhi, Y., Metcalfe, D. B., Silva-Espejo, J. E., Jiménez, E., Navarrete, D., Almeida, S., Costa, A. C. L., Salinas, N., Phillips, O. L., Anderson, L. O., Baker, T. R., Goncalvez, P. H., Huamán-Ovalle, J., Mamani-Solórzano, M., Meir, P., Monteagudo, A., Peñuela, M. C., Prieto, A., Quesada, C. A., Rozas-Dávila, A., Rudas, A., Silva Junior, J. A., and Vásquez, R.: Above- and below-ground net primary productivity across ten Amazonian forests on contrasting soils, Biogeosciences Discuss., 6, 2441-2488, 2009,

http://www.biogeosciences-discuss.net/6/2441/2009/.

Asner, G. P. and Wessman, C. A.: Scaling PAR absorption from the leaf to landscape level in spatially heterogeneous ecosystems, Ecol. Model., 103, 81-97 1997.

Baker, T. R., Swaine, M. D., and Burslem, D. F.: Variation in tropical forest growth rates: combined effects of functional group composition and resource availability Perspectives in Plant Ecology, Evolution and Systematics, 6, 21-36, 2003.

Baker, T. R., Phillips, O. L., Malhi, Y., Almeida, S., Arroyo, L., Di Fiore, A., Erwin, T., Higuchi, N., Killeen, T. J., Laurance, S. G., Laurance, W. F., Lewis, S. L., Monteagudo, A., Neill, D. A., Vargas, P. N., Pitman, N. C., Silva, J. N., and Martínez, R. V.: Increasing biomass in Amazonian forest plots, Philos. T. Roy. Soc. B, 359, 353-365, 2004a.

Baker, T. R., Phillips, O. L., Malhi, Y., Almeida, S., Arroyo, L., Di Fiore, A., Killeen, T., Laurance, S. G., Laurance, W. F., Lewis, S. L., Lloyd, J., Monteagudo, A., Neill, D. A., Patiño, S., Pitman, N. C. A., Silva, N., and Vásquez Martínez, R.: Variation in wood density determines spatial patterns in Amazonian forest biomass, Global Change Biol., 10, 545-562, 2004b.

Baker, T. R., Phillips, O. L., Laurance, W. F., Pitman, N. C. A., Almeida, S., Arroyo, L., DiFiore, A., Erwin, T., Higuchi, N., Killeen, T. J., Laurance, S. G., Nascimento, H., Monteagudo, A., Neill, D. A., Silva, J. N. M., Malhi, Y., López Gonzalez, G., Peacock, J., Quesada, C. A., Lewis, S. L., and Lloyd, J.: Do species traits determine patterns of wood production in Amazonian forests?, Biogeosciences, 6, 297-307, 2009, http://www.biogeosciences.net/6/297/2009/.

Betts, R. A., Cox, P. M., Collins, M., Harris, P. P., Huntingford, C., and Jones, C. D.: The role of ecosystem-atmosphere interactions in simulated Amazonian precipitation decrease and forest dieback under global climate warming, Theor. Appl. Climatol., 78, 137-158, 2004.

Bicheron, P., Defourny, P., Brockmann, C., Schouten, L., Vancutsem, C., Huc, M., Bontemps, S., Leroy, M., Achard, F., Herold, M., Ranera, F., and Arino, O.: Globcover, ESA / ESA GlobCover Project, available on-line: http://ionia1.esrin.esa.int/index.asp, 2008.
Bins, L. S. E. G. J. and Fonseca, L. M. G.: Um método de classificação não supervisionada por regiões, in: Simpósio Brasileiro de Computação Gráfica e Processamento de Imagens, Recife, Brazil, 1, 65-68, 1993.

Câmara, G., Souza, R. C. M., Freitas, U. M., and Garrido, J.: SPRING: Integrating remote sensing and GIS by object-oriented data modelling, Computers \& Graphics, 20, 395-403, 1996.

Chambers, J. Q., Santos, J., Ribeiro, R. J., and Higuchi, N.: Tree damage, allometric relationships, and above-ground net primary production in central Amazon forest, Forest. Ecol. Manag., 152, 73-84, 2001.

Chave, J., Condit, R., Aguilar, S., Hernandez, A., Lao, S., and Perez, R.: Error propagation and scaling for tropical forest biomass estimates, Philos. T. Roy. Soc. B, 359, 409-420 2004.

Chave, J., Andalo, C., Brown, S., Cairns, M. A., Chambers, J. Q., Eamus, D., Fölster, H., Fromard, F., Higuchi, N., Kira, T., Lescure, J.-P., Nelson, B. W., Ogawa, H., Puig, H., Riéra, B., and Yamakura, T.: Tree allometry and improved estimation of carbon stocks and balance in tropical forest, Oecologia, 145, 87-99, 2005.

Chave, J., Navarrete, D., Almeida, S., Álvarez, E., Aragão, L. E. O. C., Bonal, D., Châtelet, P., Silva Espejo, J., Goret, J.-Y., von Hildebrand, P., Jiménez, E., Patiño, S., Peñuela, M. C., Phillips, O. L., Stevenson, P., and Malhi, Y.: Regional and temporal patterns of litterfall in tropical South America, Biogeosciences Discuss., 6, 7565-7597, 2009,

http://www.biogeosciences-discuss.net/6/7565/2009/.

Clark, D. A., Brown, S., Kicklighter, D. W., Chambers, J. Q., Thomlinson, J. R., Ni, J., and Holland, E. A.: Net primary production in tropical forests: An evaluation and synthesis of existing field data, Ecol. Appl., 11, 371-384, 2001.

Clinebell II, R. R., Phillips, O. L., Gentry, A. H., Stark, N., and Zuuring, H.: Prediction of neotropical tree and liana species richness from soil and climatic data, Biodivers. Conserv., 4, 56-90, 1995.

Condit, R., Pitman, N., Leigh Jr., E. G., Chave, J., Terborgh, J., Foster, R. B., Nunez, P., Aguilar, S., Valencia, R., Villa, G., Muller-Landau, H. C., Losos, E., and Hubbell, S. P.: Beta-diversity in tropical forest trees, Science, 295, 666-669, doi:10.1126/science.1066854, 2002.

de Grandi, G. F., Mayaux, P., Malingreau, J. P., Rosenqvist, A., Saatchi, S., and Simard, M.: New perspectives on global ecosystems from wide-area radar mosaics: Flooded forest mapping in the tropics, Int. J. Remote Sens., 21, 1235-1249, 2000.

Duque, A., Cavelier, J., and Posada, A.: Strategies of tree occupation at a local scale in terra firme forests in the Colombian Amazon, Biotropica, 35, 20-27, 2003.

Fitzgerald, R. W. and Lees, B. G.: Assessing the classification accuracy of multisource remote sensing data, Rem. Sens. Environ., 47, 362-368, 1994.

Foody, G. M. and Hill, R. A.: Classification of tropical forest classes from Landsat TM data, Int. J. Rem. Sens., 17, 2353-2367, 1996.

Franklin, J. and Woodcock, C. E.: Multiscale vegetation data for the mountains of Southern California: spatial and categorical resolution, Scale in Remote Sensing and GIS, edited by: Goodchild, D. A. Q. a. M. F., CRC/Lewis 141-168 pp., 1997.

Gentry, A. H.: Tree species richness of upper Amazonian forests, P. Natl. Acad. Sci.-Biol., 85, 156-159, 1988.

Hess, L., Melack, J. M., Novo, E., Barbosa, C. C. F., and Gastil, 
M.: Dual-season mapping of wetland inundation and vegetation for the central Amazon basin, Rem. Sens. Environ., 87, 404-428, 2003.

Higuchi, N., dos Santos, J., Ribeiro, R. J., Minette, L., and Biot, Y.: Biomassa da parte aérea da vegetação da floresta tropical úmida de terra-firme da Amazônia Brasileira, Acta Amazonica, 28, 153-166, 1998.

Hill, R. A.: Image segmentation for humid tropical forest classification in Landsat TM data, Int. J. Remote Sens., 20, 1039-1044, 1999.

Honorio Coronado, E. N., Baker, T. R., Phillips, O. L., Pitman, N. C. A., Pennington, R. T., Vásquez Martínez, R., Monteagudo, A., Mogollón, H., Dávila Cardozo, N., Ríos, M., García-Villacorta, R., Valderrama, E., Ahuite, M., Huamantupa, I., Neill, D. A., Laurance, W. F., Nascimento, H. E. M., Soares de Almeida, S., Killeen, T. J., Arroyo, L., Núñez, P., and Freitas Alvarado, L.: Integrating regional and continental scale comparisons of tree composition in Amazonian terra firme forests, Biogeosciences Discuss., 6, 1421-1451, 2009,

http://www.biogeosciences-discuss.net/6/1421/2009/.

Hoorn, C.: An environmental reconstruction of the palaeo-Amazon River system (Middle to late Miocene, NW Amazonia), Palaeogeography, Palaeoclimatology, Palaeoecology, 112, pp. 187238, 1994

Houghton, R. A., Lawrence, K. T., Hackler, J. L., and Brown,S.: The spatial distribution of forest biomass in the Brazilian Amazon: A comparison of estimates, Global Change Biol., 7, 731746, 2001

Huston, M.: Soil nutrients and tree species richness in Costa Rican forests, J. Biogeogr., 7, 147-157, 1980.

Kai, L. and Muller, J. P.: Segmenting satellite imagery: A region growing scheme, Digest - International Geoscience and Remote Sensing Symposium (IGARSS), 1075-1078, 1991.

Laurance, W. F., Laurance, S. G., Ferreira, L. V., Rankin-de Merona, J. M., Gascon, C., and Lovejoy, T. E.: Biomass collapse in Amazonian forest fragments, Science, 278, 1117-1118, 1997.

Laurance, W. F., Ferreira, L. V., Rankin-de Merona, J. M., and Laurance, S. G.: Rain forest fragmentation and the dynamics of Amazonian tree communities, Ecology, 79, 2032-2040, 1998.

Lewis, S. L., Phillips, O. L., Baker, T. R., Lloyd, J., Malhi, Y., Almeida, S., Higuchi, N., Laurance, W. F., Neill, D., Silva, N., Terborgh, J., Torres Lezama, A., Vásquez, M. R., Brown, S., Chave, J., Kuebler, C., Núñez V., P., and Vinceti, B.: Concerted changes in tropical forest structure and dynamics: evidence from 50 South American long-term plots, Philos. T. Roy. Soc. B, 359, 421-436, 2004.

Malhi, Y., Phillips, O. L., Baker, T., Almeida, S., Fredericksen, T., Grace, J., Higuchi, N., Killeen, T., Laurance, W. F., Leano, C., Lloyd, J., Meir, P., Monteagudo, A., Neill, D., Nunez, P. V., Panfil, S. N., Pitman, N., Rudas, A., Salomao, R., Saleska, S., Silva, N., Silveira, M., Sombroek, W. G., Valencia, R., Vieira, I., and Vinceti, B.: An international network to understand the biomass and dynamics of Amazonian forests (RAINFOR), J. Veg. Sci., 13, 439-450, 2002.

Malhi, Y., Baker, T. R., Phillips, O., Almeida, S., Alvarez, E., Arroyo, L., Chave, J., Czimczik, C., Di Fiore, A., Higuchi, N., Killeen, T., Laurance, S. G., Laurance, W. F., Lewis, S. L., Mercado, L. M., Monteagudo, A., Neill, D. A., Pitman, N. C. A.,
Quesada, C. A., Silva, J. N. M., Vásquez Martínez, R., Terborgh, J., Vinceti, B., and Lloyd, J.: The above-ground wood productivity and net primary productivity of 100 Neotropical forests, Global Change Biol., 10, 563-591, 2004.

Malhi, Y., Wood, D., Baker, T. R., Wright, J., and Phillips, O.: regional variation of above-ground live biomass in old-growth Amazonian forests, Global Change Biol., 12, 1-32, 2006.

Malhi, Y., Roberts, J. T., Betts, R. A., Killeen, T. J., Li, W., and Nobre, C. A.: Climate change, deforestation and the fate of the Amazon, Science, 319, 169-172, 2008.

Marengo, J. A.: Characteristics and spatio-temporal variability of the Amazon River Basin Water Budget, Clim. Dynam., 24, 1122, 2005.

Muller-Landau, H. C.: Interspecific and inter-site variation in wood specific gravity of tropical trees, Biotropica, 36, 20-32, 2004.

Mercado, L. M., Lloyd, J., Dolman, A. J., Sitch, S., and Patiño, S.: Modelling basin-wide variations in Amazon forest productivity Part 1: Model calibration, evaluation and upscaling functions for canopy photosynthesis, Biogeosciences, 6, 1247-1272, 2009, http://www.biogeosciences.net/6/1247/2009/.

Nebel, G., Kvist, L. P., Vanclay, J. K., and Vidaurre, H.: Forest dynamics in flood plain forests in the Peruvian Amazon: effects of disturbance and implications for management, Forest. Ecol. Manag., 150, 79-92, 2001.

Nepstad, D. C., Verssimo, A., Alencar, A., Nobre, C., Lima, E., Lefebvre, P., Schlesinger, P., Potter, C., Moutinho, P., Mendoza, E., Cochrane, M., and Brooks, V.: Large-scale impoverishment of Amazonian forests by logging and fire, Nature, 398, 505-508, 1999.

Patiño, S., Lloyd, J., Paiva, R., Baker, T. R., Quesada, C. A., Mercado, L. M., Schmerler, J., Schwarz, M., Santos, A. J. B., Aguilar, A., Czimczik, C. I., Gallo, J., Horna, V., Hoyos, E. J., Jimenez, E. M., Palomino, W., Peacock, J., Peña-Cruz, A., Sarmiento, C., Sota, A., Turriago, J. D., Villanueva, B., Vitzthum, P., Alvarez, E., Arroyo, L., Baraloto, C., Bonal, D., Chave, J., Costa, A. C. L., Herrera, R., Higuchi, N., Killeen, T., Leal, E., Luizão, F., Meir, P., Monteagudo, A., Neil, D., NúñezVargas, P., Peñuela, M. C., Pitman, N., Priante Filho, N., Prieto, A., Panfil, S. N., Rudas, A., Salomão, R., Silva, N., Silveira, M., Soares deAlmeida, S., Torres-Lezama, A., Vásquez-Martnez, R., Vieira, I., Malhi, Y., and Phillips, O. L.: Branch xylem density variations across the Amazon Basin, Biogeosciences, 6, 545568,2009 ,

http://www.biogeosciences.net/6/545/2009/.

Peacock, J., Baker, T. R., Lewis, S. L., Lopez-Gonzalez, G., and Phillips, O. L.: The RAINFOR plot database: monitoring forest biomass and dynamics, J. Veg. Sci., 18, 542-553, 2007.

Phillips, O. L., Hall, P., Gentry, A. H., Sawyer, A. S., and Vasquez, R.: Dynamics and species richness of tropical rain forests, P. Natl. Acad. Sci.-Biol., 91, 2805-2809, 1994.

Phillips, O. L., Malhi, Y., Higuchi, N., Laurance, W. F., Nuñez Vargas, P., Vásquez Martinez, R., Laurance, S. G., Ferriera, L. V., Stern, M., Brown, S., and Grace, J.: Changes in the carbon balance of tropical forest: evidence from long-term plots, Science, 282, 439-442, 1998.

Phillips, O. L., Malhi, Y., Vinceti, B., Baker, T., Lewis, S. L., Higuchi, N., Laurance, W. F., Núñez, V. P., Vásquez, M. R., Laurance, S. G., Ferreira, L. V., Stern, M., Brown, S., and Grace, J.: Changes in growth of tropical forests: evaluating potential 
biases, Ecol. Appl., 12, 576-587, 2002.

Phillips, O. L., Núñez Vargas, P., Monteagudo, A. L., Peña Cruz, A., Chuspe Zans, M.-E., Sánchez, W.G., Yli-Halla, M., and Rose, S.: Habitat association among Amazonian tree species: a landscapescale approach, J. Ecol., 91, 757-775, 2003.

Phillips, O., Baker T. R., Arroyo, L., Higuchi, N., Killeen, T., Laurance, W. F., Lewis, S. L., Lloyd, J., Malhi, Y., Monteagudo, A., Neill, D., Núñez Vargas, P., Silva, N., Terborgh, J., Vásquez Martínez, R., Alexiades, M., Almeida, S., Brown, S., Chave, J., Comiskey, J. A., Czimczik, C. I., Di Fiore, A., Erwin, T., Kuebler, C., Laurance, S. G., Nascimento, H. E. M., Palacios, W., Patiño, S., Pitman, N., Olivier, J., Quesada, C. A., Saldias, M., Torres Lezama, A., and Vinceti, B.: Pattern and process in Amazon tree turnover, 1976-2001, Philos. T. Roy. Soc. B, 359, 381407, 2004

Phillips, O. L., Aragão, L., Fisher, J. B., Lewis, S. L., Lloyd, J., López-González, G., Malhi, Y,. Monteagudo, A., Peacock, J., Quesada, C., van der Heijden, G., Almeida, S., Amaral, I., Arroyo, L., Aymard, G., Baker, T. R., Banki, O. S., Blanc, L., Bonal, D., Brando, P., Chave, J., de Oliveira, A. C., Dávila Cardozo, N., Espejo, J., Feldpausch, T., Aparecida Freitas, M., Higuchi, N., Jiménez, E., Meir, P., Mendoza B. C., Morel, A., Neill, D., Nepstad, D., Patiño, S., Peñuela, M. C., Prieto, A., Ramírez, F., Schwarz, M., Silveira, M., Sota, A., ter Steege, H., Stropp, J., Vásquez, R., Zelazowski, P., Alvarez Dávila, E., Andelman, S., Erwin, T., di Fiore, A., Chao, K.-J., Honorio, E., Keeling, H., Killeen, T., Laurance, W., Nascimento, H., Peña Cruz, A., Pitman, N., Núñez Vargas, P., Ramírez, H., Rudas, A., Salamão, R., Silva, N., Terborgh, J., and Torres, A.: Drought sensitivity of the Amazon rainforest, Science, 323: 1344-1347, 2009.

Quesada, C. A., Lloyd, J., Anderson, L. O., Fyllas, N. M., Schwarz, M., and Czimczik, C. I.: Soils of amazonia with particular reference to the rainfor sites, Biogeosciences Discuss., 6, 3851-3921, 2009 ,

http://www.biogeosciences-discuss.net/6/3851/2009/.

Quesada, C. A., Lloyd, J., Schwarz, M., Baker, T. R., Phillips, O. L., Patiño, S., Czimczik, C., Hodnett, M. G., Herrera, R., Arneth, A., Lloyd, G., Malhi, Y., Dezzeo, N., Luizão, F. J., Santos, A. J. B., Schmerler, J., Arroyo, L., Silveira, M., Priante Filho, N., Jimenez, E. M., Paiva, R., Vieira, I., Neill, D. A., Silva, N., Peñuela, M. C., Monteagudo, A., Vásquez, R., Prieto, A., Rudas, A., Almeida, S., Higuchi, N., Lezama, A. T., López-González, G., Peacock, J., Fyllas, N. M., Alvarez Dávila, E., Erwin, T., di Fiore, A., Chao, K. J., Honorio, E., Killeen, T., Pea Cruz, A., Pitman, N., Núñez Vargas, P., Salomão, R., Terborgh, J., and Ramírez, H.: Regional and large-scale patterns in Amazon forest structure and function are mediated by variations in soil physical and chemical properties, Biogeosciences Discuss., 6, 39934057, 2009a,

http://www.biogeosciences-discuss.net/6/3993/2009/.

Quesada, C. A., Lloyd, J., Anderson, L. O., Fyllas, N. M., Schwarz, M., and Czimczik, C. I.: Soils of amazonia with particular reference to the rainfor sites, Biogeosciences Discuss., 6, 3851-3921, 2009b,

http://www.biogeosciences-discuss.net/6/3851/2009/.

Richards, J. A.: Remote Sensing Digital Analysis: An Introduction, New York: SpringerVerlag, pp. 133-154, 1993.

Rodriguez-Yi, J. L., Shimabukuro, Y. E., and Rudorff, B. F. T.: Im- age segmentation for classification of vegetation using NOAA AVHRR data, Int. J. Remote Sens., 21, 167-172, 2000.

Saatchi, S., Malhi, Y., Zutta, B., Buermann, W., Anderson, L. O., Araujo, A. M., Phillips, O. L., Peacock, J., ter Steege, H., Lopez Gonzalez, G., Baker, T., Arroyo, L., Almeida, S., Higuchi, N., Killeen, T., Monteagudo, A., Neill, D., Pitman, N., Prieto, A., Salomão, R., Silva, N., Vásquez Martínez, R., Laurance, W., and Ramrez, H. A.: Mapping landscape scale variations of forest structure, biomass, and productivity in Amazonia, Biogeosciences Discuss., 6, 5461-5505, 2009,

http://www.biogeosciences-discuss.net/6/5461/2009/.

Salo, J., Kalliola, R., Hakkinen, I., Makinen, Y., Niemela, P., Puhakka, M., and Colley, P. D.: River dynamics and the diversity of Amazon lowland forest, Nature, 322, 254-258, 1986.

Salovaara, K. J., Cárdenas, G. G., and Tuomisto, H.: Forest classification in an Amazonian rainforest landscape using pteridophytes as indicator species, Ecography, 27, 689-700, 2004.

Salovaara, K. J., Thessler, S., Malik, R. N., and Tuomisto, H.: Classification of Amazonian primary rain forest vegetation using Landsat ETM+ satellite imagery, Rem. Sens. Environ., 97, 39-51, 2005.

Shlien, S. and Smith, A.: A rapid method to generate spectral theme classification of Landsat imagery, Rem. Sens. Environ., 4, 67-77, 1975.

Stehman, S. V.: Estimating standard errors of accuracy assessment statistics under cluster sampling, Rem. Sens. Environ., 60, 258269, 1997.

Swaine, M. D. and Becker, P.: Woody-life form composition and association on rainfall and soil fertility gradients in Ghana, Plant Ecol., 145, 167-173, 1999.

Telles, E. D. C., de Camargo, P. B., Martinelli, L. A., Trumbore, S. E., da Costa, E. S., Santos, J., Higuchi, N., and Oliveira, R. C.: Influence of soil texture on carbon dynamics and storage potential in tropical forest soils of Amazonia, Global Biogeochem. Cycles, 17, 1-9, 2003.

ter Steege, H., Sabatier, S., Castellanos, H., van Andel, T., Duivenvoorden, J., de Oliveira, A. A., Ek, R. C., Lilwah, R., Maas, P. J. M., and Mori, S. A.: An analysis of Amazonian floristic composition, including those of the Guiana Shield, J. Tropical Ecol., $16,801-828,2000$.

ter Steege, H., Pitman, N. C. A., Phillips, O. L., Chave, J., Sabatier, D., Duque, A., Molino, J.-F., Prévost, M.-F., Spichiger, R., Castellanos, H., von Hildebrand, P., and Vásquez, R.: Continental-scale patterns of canopy tree composition and function across Amazonia, Nature, 443, 444-447, 2006.

Tuomisto, H. and Ruokolainen, K.: Distribution of Pteridophyta and Melastomataceae along an edaphic gradient in an Amazonian rain forest, J. Veg. Sci., 5, 25-34, 1994.

Tuomisto, H., Ruokolainen, K., and Yli-Halla, M.: Dispersal, environment, and floristic variation of western Amazonian forests, Science, 299, 241-244, doi:10.1126/science.1078037, 2003.

Worbes, M.: The forest ecosystem of the floodplains, The Central Amazon Floodplain, edited by: Junk, W. J., Springer, Berlin, 223-266 pp., 1997.

Wright, S. J.: Seasonal drought, soil fertility and the species density of tropical forest plant communities, Trends Ecol. Evol., 7, 260263, 1992.

Zonneveld, I.: The land unit: a fundamental concept on Landscape ecology, Landscape Ecol., 3, 67-89, 1989. 